\title{
The political economy of imperialism, decolonization, and development
}

Gartzke, Erik ; Rohner, Dominic

\begin{abstract}
Nations have historically sought power and prosperity through control of physical space. In recent decades, however, this has largely ceased. Most states that could do so appear relucant, while the weak cannot expand. This article presents a theory of imperialism and decolonization that explains both historic cycles of expansion and decline and the collective demise of the urge to colonize. Technological shocks enable expansion, while rising labour costs and the dynamics of military technology gradually dilute imperial advantage. Simultaneously, economic development leads to a secular decline in payoffs for appropriating land, minerals and capital. Once conquest no longer pays great powers, the systemic imperative to integrate production vertically also becomes archaic.
\end{abstract}

DOI: https://doi.org/10.1017/S0007123410000232

Posted at the Zurich Open Repository and Archive, University of Zurich

ZORA URL: https://doi.org/10.5167/uzh-55599

Journal Article

Published Version

Originally published at:

Gartzke, Erik; Rohner, Dominic (2011). The political economy of imperialism, decolonization, and development. British Journal of Political Science, 41(3):525-556.

DOI: https://doi.org/10.1017/S0007123410000232 


\section{British Journal of Political Science}

http://journals.cambridge.org/JPS

British

Journal of

Political

Additional services for British Journal of Political Science:

Science

Email alerts: $\underline{\text { Click here }}$

Subscriptions: $\underline{\text { Click here }}$

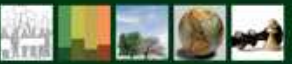

Commercial reprints: Click here

Terms of use : Click here

CAMsmioc:

\section{The Political Economy of Imperialism, Decolonization and Development}

Erik Gartzke and Dominic Rohner

British Journal of Political Science / Volume 41 / Issue 03 / July 2011, pp 525 - 556

DOI: 10.1017/S0007123410000232, Published online: 01 February 2011

Link to this article: http://journals.cambridge.org/abstract_S0007123410000232

How to cite this article:

Erik Gartzke and Dominic Rohner (2011). The Political Economy of Imperialism, Decolonization and Development. British Journal of Political Science, 41, pp 525-556 doi:10.1017/ S0007123410000232

Request Permissions : $\underline{\text { Click here }}$ 


\title{
The Political Economy of Imperialism, Decolonization and Development
}

\author{
ERIK GARTZKE AND DOMINIC ROHNER*
}

\begin{abstract}
Nations have historically sought power and prosperity through control of physical space. In recent decades, however, this has largely ceased. Most states that could do so appear relucant, while the weak cannot expand. This article presents a theory of imperialism and decolonization that explains both historic cycles of expansion and decline and the collective demise of the urge to colonize. Technological shocks enable expansion, while rising labour costs and the dynamics of military technology gradually dilute imperial advantage. Simultaneously, economic development leads to a secular decline in payoffs for appropriating land, minerals and capital. Once conquest no longer pays great powers, the systemic imperative to integrate production vertically also becomes archaic.
\end{abstract}

'Other nations in history have fought in foreign lands and remained to occupy and exploit. Americans, following a battle, want nothing more than to return home ...'

George W. Bush

Two recent American wars in the Middle East have reawakened discussions of American Empire. ${ }^{1}$ In contrast to traditional patterns, however, the United States appears to have no desire to acquire more territory. Whether empire requires physical expansion and colonization, or simply 'effective control' of another society, ${ }^{2}$ seems to us to be largely definitional. $^{3}$ Labelling American motives and practices as imperial, hegemonic or something else is perhaps less critical than attempting to understand why such behaviour

* Department of Political Science, University of California-San Diego (email: egartzke@ucsd.edu); Department of Economics, University of Zurich, respectively. The authors wish to thank Victor Asal, Alexander Cooley, Eugene Gholz, Lucy Goodhart, three referees and the Editor for comments. Vsevolod Gunitskiy provided research assistance. A version of this article was presented at the meeting of the Peace Science Society (International) in Columbus, Ohio, 2006. Dominic Rohner gratefully acknowledges financial support from the Swiss National Science Foundation (SNF grant no. 100014-122636). All data and a STATA 'do' file that replicates the analysis are available from the authors upon publication.

${ }^{1}$ Chalmers Johnson, Blowback: The Costs and Consequences of American Empire (New York: Owl Books, 2001); Chalmers Johnson, The Sorrows of Empire: Militarism, Secrecy, and the End of the Republic (New York: Metropolitan Books, 2004); Andrew J. Bacevich, American Empire: The Realities and Consequences of US Diplomacy (Cambridge, Mass.: Harvard University Press, 2002); Niall Ferguson, Colossus: The Price of America's Empire (New York: Penguin, 2004).

${ }_{2}$ Michael W. Doyle, Empires (Ithaca, N.Y.: Cornell University Press, 1986), p. 30.

${ }^{3}$ Niall Ferguson prefers the term 'empire' to 'hegemony'. 'To compare . . . the United States and the United Kingdom as hegemonies is to miss differences that become obvious when the two are compared as empires.' Distinguishing between US hegemony and British empire would highlight the differences Ferguson seeks to emphasize: 'A century ago, the United Kingdom's formal empire was very large indeed, covering nearly a quarter of the world's surface and ruling roughly the same proportion of its population. Today, on the other hand, the United States' formal empire includes just 14 dependencies (of which the largest is Puerto Rico) and covers less than 11,000 square kilometers.' (Niall Ferguson, 'Hegemony or Empire? Book Review', Foreign Affairs, 82 (2003), pp. 160-1.) 
exists and evolves over time. ${ }^{4}$ We seek to explain the acquisition or abandonment of colonial holdings, offering an account that ties together the rise and fall of territorial expansion with the current American penchant for influence rather than long-term occupation. Developed nations exhibit little of the traditional preoccupation with obtaining land and resources through force. The appeal of colonial holdings evaporated for leading nations by the mid-twentieth century. Rather than reflecting an exception to traditional tendencies, American efforts represent secular change in the imperatives of power; owning land or minerals matters much less than guiding the global commons.

One of the defining characteristics of the modern world has been the cycle of the European empire. In it, the familiar pattern of expansion and contraction is readily discernible. ${ }^{5}$ Yet while acts viewed as 'imperialist' may persist today, no nation or set of nations has come forward to pick up the gauntlet of empire. The world's richest and most powerful countries show little interest in the continuous administration of foreign territory, as opposed to attempting to influence, intimidate or coerce foreign sovereigns and polities. These same powers are also vigorously opposed to allowing other countries to pursue any territorial ambitions. What some have labelled a norm of territorial integrity seems to us to require further explanation. ${ }^{6}$ What motivates an end of empire? Can we expect this phenomenon to continue or will the future return to historical patterns of imperial growth and decay? The notion of American Exceptionalism implies that other, less 'exceptional' nations will someday resurrect these more traditional patterns. China or India, for example, might use growing economic and military potential to expand at the expense of their neighbours. Alternatively, rising powers may find that control of physical space is best accomplished by proxy, ensuring that other countries accommodate Beijing or Delhi, rather than by actually having to conquer, and administer, marginally productive places that are geographically distant from the metropolis.

We offer a theory of imperialism and decolonization based on the dynamics of systemic structure, military technology and economic development. Random capability shocks create military advantages that gradually decay as insights fade or equipment becomes outdated or as accumulating capital forces a change in the logic of military organization that dilutes initial military advantages. Military capability shocks by themselves can explain the cycle of empire, but not the secular trend away from territorial expansion. A second feature, economic development, has led nations gradually to prefer commerce to conquest. Capital abundance makes empire expensive, shifting incentives away from appropriating inputs to production and towards efforts to influence the terms under which nations interact. A third element explains the timing and rapidity of decolonization. Conquest imparts political control that invites the vertical integration of economic processes. Mercantilism in turn impels other countries to acquire or maintain colonies in order to access markets and inputs to production. This imperialist prisoner's dilemma is reversed once influential actors prefer free market policies, allowing other countries to abandon empire as well. The theory predicts

${ }^{4}$ President Hugo Chavez of Venezuela recently claimed in the United Nations that the United States was led by 'the devil'.

${ }^{5}$ See, for example, Edward Gibbon, The Decline and Fall of the Roman Empire (New York: Knopf, 1993[1776]); Oswald Spengler, The Decline of the West (London: Allen \& Unwin, 1932); George A. Modelski, Long Cycles in World Politics (Seattle: University of Washington Press, 1987).

${ }^{6}$ Mark Zacher, 'The Territorial Integrity Norm: International Boundaries and the Use of Force', International Organization, 55 (2001), 215-50; Tanisha Fazal, State Death: The Politics and Geography of Conquest, Occupation, and Annexation (Princeton, N.J.: Princeton University Press, 2007). 
that territorial empire is archaic. Power in the modern world derives from productivity rather than from raw materials. The lust for land could return, however, if inputs again become scarce, if military technology lowers occupation costs, or if powerful nations fail to perpetuate and abet open markets.

\section{LITERATURE: TROPES OF EMPIRE}

Lasting over three and a half centuries, the age of imperialism profoundly shaped the modern world. The classical practice of territorial expansion virtually ended soon after the Second World War, but the institutions and economies of the often contrived successor nations formed to manage abandoned colonial holdings remain heavily conditioned by their dependency. ${ }^{7}$ Territorial imperialism has been widely criticized both during ${ }^{8}$ and after its formal practice. ${ }^{9}$ Considerable attention also focused on the consequences of decolonization. ${ }^{10}$ Yet, while many scholars examine the origins of empire, ${ }^{11}$ its practice ${ }^{12}$ or demise, ${ }^{13}$ less effort has been devoted to relating historical cycles of expansion and decay to the secular, and precipitous, terminus of territorial empire in the mid-twentieth century. ${ }^{14}$

7 See, for example, Douglass North, Structure and Change in Economic History (New York: Norton, 1981); Daron Acemoglu, Simon Johnson and James A. Robinson, 'The Colonial Origins of Comparative Development: An Empirical Investigation', American Economic Review, 91 (2001), 1369-1401; Hendrik Spruyt, Ending Empire: Contested Sovereignty and Territorial Partition (Ithaca, N.Y.: Cornell University Press, 2005).

${ }^{8}$ John A. Hobson, Imperialism (Ann Arbor: University of Michigan Press, 1938 [1905]); V. I. Lenin, Imperialism: The Highest Stage of Capitalism (New York: International Publishers, 1970 [1916]); George Orwell, Shooting an Elephant and Other Essays (New York: Harcourt, Brace \& Co., 1950); Jean-Paul Sartre, Colonialism and Neocolonialism (London: Routledge, 2001).

9 Edward W. Said, Culture and Imperialism (New York: Knopf, 1993); Edward W. Said, Orientalism (New York: Vintage Books, 1994); Edward W. Said, 'Yeats and Decolonization', in Moustafa Bayoumi and Andrew Rubin, eds, The Edward Said Reader (New York: Vintage Books, 2000); Noam Chomsky, Hegemony or Survival: America's Quest for Global Dominance (New York: Metropolitan Books, 2003); Johnson, Blowback; and Johnson, The Sorrows of Empire.

${ }^{10}$ John Darwin, Britain and Decolonization: The Retreat from Empire in the Post-War World (New York: St. Martin's, 1988); Raymond F. Betts, Decolonization (London: Routledge, 1998).

${ }^{11}$ Tony Smith, The Pattern of Imperialism: The United States, Great Britain, and the LateIndustrializing World since 1815 (Cambridge: Cambridge University Press, 1981); Geoffrey Scammell, The First Imperial Age: European Overseas Expansion c. 1400-1715 (Boston, Mass.: Unwin-Hyman, 1989); Nicholas Canny, ed., The Oxford History of the British Empire: Vol. I: The Origins of Empire: British Overseas Enterprise to the Close of the Seventeenth Century (New York: Oxford University Press, 2001); Jeremy Black, Europe and the World, 1650-1830 (New York: Routledge, 2002).

12 Heinz Gollwitzer, Europe in the Age of Imperialism, 1880-1914 (New York: Harcourt, Brace \& Co., 1969); Peter J. Cain and Anthony G. Hopkins, British Imperialism: Innovation and Expansion, 1688-1914 (London: Longman, 1993).

13 Alexander Motyl, Imperial Ends: The Decay, Collapse and Revival of Empires (New York: Columbia University Press, 2001); Johan Galtung, Tore Heiestad and Erik Rudeng, 'On the Decline and Fall of Empires: The Roman Empire \& Western Imperialism Compared', Review (Fernand Braudel Center), 4 (1980), 91-153; Johan Galtung, The Decline and Fall of Empires: A Theory of Re-Development (Geneva: Research Institute on Development (UNRISD), 1996); John Springhall, Decolonization Since 1945: The Collapse of European Empires Overseas (New York: Palgrave, 2001).

14 Our argument is by no means incompatible with the view that moral suasion helped to end empire. See, for example, Robert Jackson, 'The Weight of Ideas in Decolonization: Normative Change in International Relations', in Judith Goldstein and Robert O. Keohane, eds, Ideas and Foreign Policy: Beliefs, Institutions, and Political Change (Ithaca, N.Y.: Cornell University Press, 1993), pp. 111-38; Neta Crawford, Argument and Change in World Politics: Ethics, Decolonization, and Humanitarian Intervention 
Explorations of contemporary imperialism seem more rhetorical and didactic than deductive or analytical. ${ }^{15}$ Discussion of American empire has ebbed and flowed with shifting American power, ${ }^{16}$ and with a variable landscape of international actors. ${ }^{17}$ Careful research has focused on an evolving logic of hierarchy, ${ }^{18}$ or on the role of American hegemony in deterring territorial aggression. ${ }^{19}$ Absent is an account of why, in fact, things are not more like they used to be.

\section{Explanations for Imperialism}

Explanations for empire focus on the demand of the metropolis for riches, resources, markets or jobs; on the supply of targets for conquest; or on system-level factors that condition colonial opportunities or demand. ${ }^{20}$ Hobson, Lenin and others claimed that the imperial impetus comes from over-extended capitalism. ${ }^{21}$ Snyder views instead political and military elites as the cause of empire, while jingoistic propaganda deceives the masses. ${ }^{22}$ Dependency theorists shift the emphasis to political tensions and economic incentives on the periphery. ${ }^{23}$

(F'note continued)

(Cambridge: Cambridge University Press, 2002). Yet to use such arguments runs the risk of being overly congratulatory about the triumph of Western ethics over Western avarice. Western civilization set aside ethical qualms for hundreds of years. The very dawn of empire is punctuated by acts like the encomiendo that nominally guaranteed Church protection in the New World, but which effectively gave authorities a free hand with indigenous populations.

15 Johnson, Blowback; Johnson, The Sorrows of Empire; Ferguson, Colossus.

16 Arthur Schlesinger Jr, The Cycles of American History (Boston, Mass.: Houghton Miffin, 1986); Paul Kennedy, Rise and Fall of the Great Powers: Economic Change \& Military Conflict from 1500 to 2000 (New York: Random House, 1989).

17 Andrew J. Bacevich, American Empire: The Realities and Consequences of US Diplomacy (Cambridge, Mass.: University of Harvard Press, 2002).

18 David Lake, 'Anarchy, Hierarchy, and the Variety of International Institutions', International Organization, 50 (1996), 1-33; Alexander Cooley, Logics of Hierarchy (Ithaca, N.Y.: Cornell University Press, 2005).

19 Zacher, 'The Territorial Integrity Norm'; Fazal, State Death.

${ }^{20}$ Our comments on the literature are necessarily brief. They are not intended as a thorough or balanced representation of available perspectives. Instead, we focus on contemporary debates and our own view of salient controversies.

${ }^{21}$ Hobson, Imperialism; Lenin, Imperialism. For reviews and criticism, see David K. Fieldhouse, “"Imperialism": An Historiographical Revision', Economic History Review, 14 (1961), 187-209; David K. Fieldhouse, The Theory of Capitalist Imperialism (London: Longman, 1967); Rajan Menon and John R. Oneal, 'Explaining Imperialism: The State of the Art in Three Theories', Polity, 19 (1986), 169-93; A. M. Eckstein, 'Is There a "Hobson-Lenin Thesis" on Late Nineteenth-Century Colonial Expansion?' Economic History Review, 44 (1991), 297-318; Patrick Wolfe, 'History and Imperialism: A Century of Theory, from Marx to Postcolonialism', American History Review, 102 (1997), 388-420.

22 Jack L. Snyder, Myths of Empire: Domestic Politics and International Ambition (Ithaca, N.Y.: Cornell University Press, 1991).

${ }^{23}$ John Gallagher and Ronald Robinson, 'The Imperialism of Free Trade', Economic History Review, 6 (1953), 1-15; Theotonio Dos Santos, 'The Structure of Dependence', American Economic Review, 60 (1970), 231-6; Johan Galtung, 'A Structural Theory of Imperialism', Journal of Peace Research, 8 (1971), 81-117; James A. Caporaso, 'Dependence, Dependency, and Power in the Global System: A Structural and Behavioral Analysis', International Organization, 32 (1998), 14-43. For criticism, see Elisabeth Gidengil, 'Centres and Peripheries: An Empirical Test of Galtung's Theory of Imperialism', Journal of Peace Research, 15 (1978), 51-66; Tony Smith, 'The Underdevelopment of Development Literature: The Case of Dependency Theory', World Politics, 31 (1979), 247-88; Erich Weede and Horst Tiefenbach, 'Some Recent Explanations of Income Inequality: An Evaluation \& Critique', International Studies Quarterly, 25 (1981), 255-82. 
Agents co-opted by the metropolis undermine developing nations. A third category of argument involves structural theories from realists, ${ }^{24}$ to Marxist historians like Wallerstein, ${ }^{25}$ to long-cycle theorists. ${ }^{26}$ Empires expand or contract in an organic fashion, responding in an unending cycle of world power or prosperity.

\section{Explanations for Decolonization}

Scholarship on the end of empire can be grouped by supply-side, demand-side and systemstructural approaches. Some researchers emphasize domestic politics in the metropolis. ${ }^{27}$ The need of landed nobles to provide employment for 'second sons' may have dissipated with the rise of other more fungible forms of property. Alternately, democracy itself may have shifted the domestic political calculus. A second perspective emphasizes colonial resistance and/or the decline of the European educated 'comprador' class of native elites. ${ }^{28}$ Finally, other researchers favour international factors, such as the 'demonstration effect' of initial Japanese victories over the Western colonial powers in the Second World War, or the rise of an antiimperialist bipolar system during the Cold War. ${ }^{29}$

\section{Putting Together Growth and Decay}

Students of world affairs have long been interested in the rise and fall of great powers. ${ }^{30}$ The 'world-economy' approach has been particularly influential in conjunction with the

24 Kenneth N. Waltz, Man, the State, and War (New York: Columbia University Press, 1959); Robert Gilpin, War and Change in World Politics (New York: Cambridge University Press, 1981).

${ }^{25}$ Immanuel Wallerstein, The Capitalist World Economy (Cambridge: Cambridge University Press, 1979).

26 Modelski, Long Cycles in World Politics; George Modelski and William R. Thompson, Seapower in Global Politics, 1494-1993 (Seattle: University of Washington Press, 1988); Joshua S. Goldstein, Long Cycles: Prosperity and War in the Modern Age (New Haven, Conn.: Yale University Press, 1988); William R. Thompson, On Global War: Historical-Structural Approaches to World Politics (Columbia: University of South Carolina Press, 1988); Christopher Chase-Dunn and Richard Rubinson, 'Toward a Structural Perspective on the World-System', Politics and Society, 7 (1979), 453-76; Christopher Chase-Dunn, Yukio Kawano and Benjamin Bewer, 'Trade Globalization Since 1795: Waves of Integration in the World-System', American Sociological Review, 65 (2000), 77-95. For an effort to tie together long-cycle theory with theories of imperial growth and decline, see Brian M. Pollins and Kevin P. Murrin, 'Where Hobbes Meets Hobson: Core Conflict and Colonialism, 1495-1985', International Studies Quarterly, 43 (1999), 427-54. For a review of long-cycles research, see Karen Rasler and William R. Thompson, 'Global War and the Political Economy of Structural Change', in Manus I. Midlarsky, ed., The Handbook of War Studies (Ann Arbor: University of Michigan Press, 2000), pp. 301-33. For criticism, see Nathaniel Beck, 'The Illusion of Cycles in International Relations', International Studies Quarterly, 35 (1991), 455-76; and Gerald Silverberg, 'Long Waves in Global Warfare and Maritime Hegemony? A Complex Systems Perspective', in Tessaleno C. Devezas, ed., Kondratieff Waves, Warfare and World Security (Amsterdam: IOS Press, 2006), pp. 154-64.

27 Miles Kahler, Decolonization in Britain and France: The Domestic Consequences of International Relations (Princeton, N.J.: Princeton University Press, 1984); Roy Holland, European Decolonization, 1918-1981: An Introductory Survey (New York: St. Martin's, 1985).

${ }^{28}$ Stuart C. Easton, The Rise and Fall of Western Colonialism (New York: Praeger, 1964); Henri Grimal, Decolonization: The British, French, Dutch and Belgian Empires (London: Routledge, 1978); D. A. Low, Eclipse of Empire (Cambridge: Cambridge University Press, 1991).

29 David McIntyre, Commonwealth of Nations: Origins and Impact (Minneapolis: University of Minnesota Press, 1977); Brian Lapping, End of Empire (London: Granada, 1985).

${ }^{30}$ See Gibbon, The Decline and Fall of the Roman Empire; A. T. Mahan, The Influence of Sea Power on History, 1660-1783, 5th edn (New York: Dover, 1987 [1890]); John J. Mearsheimer, The Tragedy of Great Power Politics (New York: W. W. Norton, 2001). 
dependency theory. ${ }^{31}$ Inequality varies between core and periphery. ${ }^{32}$ Economic stagnation leads to imperial conquest, while booms reduce interest in colonial holdings. The world-economy model thus pays more attention to long economic cycles than to the variable costs of colonial occupation.

Economic determinists stress that imperialism is the inevitable product of capitalist expansion. ${ }^{33}$ Changes in the economies of capitalist countries forced Western powers to seek dependencies that continue today in the post-colonial periphery. ${ }^{34}$ However, Marxist thinkers in particular are less interested in explicating the forces driving divestment of colonial holdings.

Institutionalism emphasizes political and social factors as the leading determinants of imperial growth and decay. ${ }^{35}$ Empire and decolonization result from shifting power relations among beneficiaries and those hurt by colonialism. ${ }^{36}$ Competition is intensified by political liberalization in the metropolis, ${ }^{37}$ or by metropolitan cultural traditions. ${ }^{38}$ Yet institutionalists face a heavy burden in explaining the persistent impotence of anti-colonialist ideas, as well as their sudden salience. Rapid decolonization, in a context of dramatic economic change, suggests the value of economic incentives in bolstering institutionalist arguments. Indeed, as the other two approaches make clear, many view the colonial enterprise as fundamentally economic, even as other factors play significant roles.

31 Dos Santos, The Structure of Dependence; Andre Gunder Frank, 'The Development of Underdevelopment', Monthly Review, 18 September 1966.

32 Immanuel Wallerstein, The Modern World System I: Capitalist Agriculture and the Origins of the European World-Economy in the Sixteenth Century (New York: Academic Press, 1974); Immanuel Wallerstein, 'The Three Instances of Hegemony in the History of the Capitalist World-Economy', International Journal of Comparative Sociology, 24 (1983), 100-8; Galtung, 'A Structural Theory of Imperialism'; Gidengil, 'Centres and Peripheries'; Chase-Dunn and Rubinson, 'Toward a Structural Perspective on the World-System'; Patrick McGowan and Bohdan Kordan, 'Imperialism in WorldSystem Perspective: Britain 1870-1914', International Studies Quarterly, 25 (1981), 43-68; Karen Rasler and William R. Thompson, 'Global Wars, Public Debts, and the Long Cycle', World Politics, 35 (1983), 489-516.

33 Karl Marx, 'The East India Company: Its History and Results', in Karl Marx, Fredrick Engels: Collected Works (New York: International Publishers, 1975 [1853]), pp. 148-56; Hobson, Imperialism; Lenin, Imperialism.

34 Gallagher and Robinson, 'The Imperialism of Free Trade'; Henry Magdoff, The Age of Imperialism: The Economics of U.S. Foreign Policy (New York: Monthly Review Press, 1969); Theodore H. Moran, 'Multinational Corporations and Dependency: A Dialogue for Dependentistas and Non-Dependentistas', International Organization, 32 (1978), 79-100.

35 David Strang, 'From Dependency to Sovereignty: An Event History Analysis of Decolonization 1870-1987', American Sociological Review, 55 (1990), 846-60; David Strang, 'Anomaly and Commonplace in European Political Expansion: Realist and Institutional Accounts', International Organization, 45 (1991), 143-62.

${ }^{36}$ See, for example, Benjamin J. Cohen, The Question of Imperialism: The Political Economy of Dominance and Dependence (New York: Basic Books, 1973); Miles Kahler, 'Political Regime and Economic Actors: The Response of Firms to the End of Colonial Rule', World Politics, 33 (1981), 383-412; Mitsuhiko Kimura, 'The Economics of Japanese Imperialism in Korea, 1910-1939', Economic History Review, 48 (1995), 555-74; Nuno R. Garoupa and João E. Gata, 'War and Peace: The European Decolonization Process' (Working Paper, Department of Economics at the School of Economics and Management, Technical University of Lisbon, 2001).

${ }^{37}$ Miles Kahler, 'External Ambition and Economic Performance', World Politics, 40 (1988), 419-51.

38 Anthony Pagden, Lords of All the World: Ideologies of Empire in Spain, Britain and France, 1500-1800 (New Haven, Conn.: Yale University Press, 1995); David Armitage, The Ideological Origins of the British Empire (Cambridge: Cambridge University Press, 2000). 
Only a few studies attempt to explore intensively the micro-foundations for colonial expansion and decline. According to Grossman and Iyigun, investments in colonies could be profitable due to monopoly rents, provided that the risk of insurrection is low. ${ }^{39}$ Increasing the insurrection technology or size of local populations could make colonization unprofitable, eventually triggering an abandonment of empire. ${ }^{40}$ These studies rely on largely exogenous changes in the colony to explain the end of empire. Nationalism or insurgency could make colonialism more expensive. ${ }^{41}$ But these same challenges confront domestic sovereigns who nevertheless strive to retain power. It seems unlikely that these changes alone explain the rapid and widespread divestment of colonial holdings. The question of why modernity has trended away from empire remains to be explained.

\section{TERRITORY 'AIN'T WHAT IT USED TO BE': CYCLES AND TRENDS}

We offer a theory combining the flow, ebb, persistence and demise of territorial empire that focuses on three factors. First, exogenous military capability shocks create the opportunity to reallocate territory through colonization. ${ }^{42}$ Secondly, occupation encourages mercantilist economic policies, in turn increasing incentives for other nations to acquire colonies. Finally, development produces a secular decline in the value of colonial holdings, while making occupation less efficient. Other influences on empire, including democratization in the metropolis, and nationalist sentiments and resistance movements in the colony, are explored in the modelling section and in two appendices. ${ }^{43}$

${ }^{39}$ Herschel Grossman and Murat Iyigun, 'The Profitability of Colonial Investment', Economics and Politics, 7 (1995), 229-41. For a debate on 'gentlemanly capitalism', see Peter J. Cain and Anthony G. Hopkins, 'The Political Economy of British Expansion Overseas, 1750-1914', Economic History Review, 33 (1980), 463-90; Peter J. Cain and Anthony G. Hopkins, 'Gentlemanly Capitalism and British Expansion Overseas I: The Old Colonial System, 1688-1850', Economic History Review, 39 (1986), 501-25; Patrick O'Brien, 'Imperialism and the Rise and Decline of the British Economy, 1688-1989', New Left Review, 1, No. 238 (1999), 48-80; Patrick O'Brien, 'Mercantilism and Imperialism in the Rise and Decline of the Dutch and British Economies', De Economist, 148 (2000), 469-501; Nicholas J. White, 'The Business and the Politics of Decolonization: The British Experience in the Twentieth Century', Economic History Review, 53 (2000), 544-64.

${ }^{40}$ Herschel Grossman and Murat Iyigun, 'Population Increase and the End of Colonialism', Economica, 64 (1997), 483-93. For a claim that colonial investments were profitable, see John R. Oneal and Frances H. Oneal, 'Hegemony, Imperialism, and the Profitability of Foreign Investments', International Organization, 42 (1988), 347-73. For an argument that investment and colonial control were interrelated, see Jeffry A. Frieden, 'International Investment and Colonial Control: A New Interpretation', International Organization, 48 (1994), 559-93. Capital flowed to middle-income countries, rather than to colonies. See Michael A. Clemens and Jeffrey G. Williamson, 'Where Did British Foreign Capital Go?' (Cambridge, Mass.: NBER Working Paper 8028, 2000), and also Sidney Pollard, 'Capital Exports, 1870-1914: Harmful or Beneficial?' Economic History Review, 2nd ser. 38 (1985), 489-514; Sidney Pollard, 'Comment on Peter Temin's Comment', Economic History Review, 2nd ser. 40 (1987), 452-8; Peter Temin, 'Capital Exports, 1870-1914: An Alternative Model', Economic History Review, 2nd ser. 40 (1987), 453-8; V. N. Balasubramanyam, 'Capital Exports, 1870-1914', Economic History Review, 42 (1989), 260-4.

${ }^{41}$ Ernest Gellner, Nations and Nationalism (Ithaca, N.Y.: Cornell University Press, 1983); James D. Fearon and David D. Laitin, 'Ethnicity, Insurgency, and Civil War', American Political Science Review, 97 (2003), 75-90.

${ }^{42}$ Military advantage can lead to other forms of hierarchy, such as vassal states, which we do not explore here.

${ }^{43}$ All appendices are available online at: http://www.journals.cambridge.org/jps. 


\section{Military Effectiveness: The Onset and Diffusion of Shock and Awe}

Anecdote and logic suggest that the advent of empire is closely tied to the ability and incentive to project power. ${ }^{44}$ Empire generally begins with new military, economic, transportation or logistical technology that suddenly allows one country to conquer and control other states or territories. ${ }^{45}$ Capability shocks are thus a necessary, but not sufficient, condition for imperial expansion. Conversely, military and other advantages borne of technological innovation diffuse over time. Targets of empire have incentives to adapt, absorbing technologies and limiting or eliminating advantages of the imperial power. ${ }^{46}$ Unless the imperial power continues to innovate, it eventually declines. ${ }^{47}$ As one British historian describes the situation, 'we had a comparative advantage as an island seapower. It was then enlarged and sustained because we secured the further comparative advantage of being the world's first industrial nation. These advantages first shrank and then disappeared. ${ }^{48}$

European expansion and colonization took place in the context of dramatic increases in the administrative, transportation and military capabilities of European states. ${ }^{49}$

44 J. F. C. Fuller, Armament and History: A Study of the Influence of Armament on History from the Dawn of Classical Warfare to the Second World War (London: Scribner, 1945); William H. McNeill, The Rise of the West: A History of the Human Community (Chicago: University of Chicago Press, 1963); William H. McNeill, The Pursuit of Power: Technology, Armed Force, and Society Since A.D. 1000 (Chicago: University of Chicago Press, 1984); William H. McNeill, 'World History and the Rise and Fall of the West', Journal of World History, 9 (1998), 215-36; Martin van Creveld, Technology and War: From 2000 B.C. to the Present (New York: The Free Press, 1989); Trevor N. Dupuy, The Evolution of Weapons and Warfare (Cambridge, Mass.: Da Capo Press, 1990).

45 Daniel R. Headrick, The Tools of Empire: Technology and European Imperialism in the Nineteenth Century (Oxford: Oxford University Press, 1981). It is easy to overemphasize technology, or confuse power projection with combat effectiveness. Leadership and personnel also remain important. See Trevor N. Dupuy, Numbers, Predictions and War: Using History to Evaluate Combat Factors and Predict the Outcome of Battles (Fairfax, Va.: Hero Books, 1979); Allan R. Millett, Williamson Murray and Kenneth H. Watman, 'The Effectiveness of Military Organizations', International Security, 11 (1986), 37-71; Allan Stam and Dan Reiter, 'Democracy, War Initiation, and Victory', American Political Science Review, 92 (1998), 377-89; Allan Stam and Dan Reiter, 'Democracy and Battlefield Military Effectiveness', Journal of Conflict Resolution, 42 (1998), 259-77; Dan Reiter and Allan C. Stam, Democracies At War (Princeton, N.J.: Princeton University Press, 2002); Ralph Rotte and Christoph M. Schmidt, 'On the Production of Victory: Empirical Determinants of Battlefield Success in Modern War', Defense and Peace Economics, 14 (2003), 175-92; Stephen Biddle, Military Power: Explaining Victory and Defeat in Modern Battle (Princeton, N.J.: Princeton University Press, 2004); Kier A. Lieber, War and the Engineers: The Primacy of Politics over Technology (Ithaca, N.Y.: Cornell University Press, 2005).

46 Barry Buzan and Eric Herring, The Arms Dynamic in World Politics (Boulder, Colo.: Lynne Rienner, 1998); Keith Krause, Arms and the State: Patterns of Military Production and Trade (New York: Cambridge University Press, 1992); Emily O. Goldman and Richard Andres, 'Systemic Effects of Military Innovation and Diffusion', Security Studies, 8 (1999), 79-125; Emily O. Goldman and Leslie C. Eliason, eds, Diffusion of Military Technology and Ideas (Palo Alto, Calif.: Stanford University Press, 2003). Colonizers and local populations engage in a strategic game: 'The logic of Western superiority in fixed encounters had been thoroughly digested by the Indians: after their costly initial defeats, they were scrupulously careful to avoid pitched battles - much to the fury of the Europeans - because they always lost them. Only gradually did the Europeans recognize that the only way to beat the Indians was to adopt those same guerrilla methods ... But the Indians of New England were also learning fast' (Geoffrey Parker, The Military Revolution: Military Innovation and the Rise of the West, 1500-1800 (Cambridge: Cambridge University Press, 1988), p. 119).

47 Gibbon, The Decline and Fall of the Roman Empire; Kennedy, Rise and Fall of the Great Powers; Gilpin, War and Change in World Politics.

${ }^{48}$ Low, Eclipse of Empire, p. 6.

49 Douglass C. North and Robert Paul Thomas, The Rise of the Western World: A New Economic History (New York: Cambridge University Press, 1973); Richard Bean, 'War and the Birth of the Nation 
This transformation and its consequences for European politics are discussed elsewhere. ${ }^{50}$ Accounts of the origins of these dramatic increases in capabilities vary. Some authors argue that harsh competition pushed European powers to develop more powerful arms and armies. ${ }^{51}$ Others emphasize financial innovations which permitted powerful militaries, and particularly navies. ${ }^{52}$ Still other research identifies a symbiosis in which states promoted a European state system, which in turn privileged states as actors. ${ }^{53}$ For our purposes, identifying the origins of these innovations is less pertinent than explaining why waves of technological and administrative change propelled adventurers, then armies, to distant places and why this impetus later ebbed and evaporated, and has not returned. $^{54}$

The cyclical nature of empire, ${ }^{55}$ and of military advantage, ${ }^{56}$ are well established, if somewhat stylized, empirical facts. What is less well understood is whether there exists variation in the motivation for empire. Some scholars argue that the urge to conquer is ubiquitous, occurring in all nations at all times and held in check only by the lack of technological advantage or martial expertise, or alternatively by mutual deterrence. ${ }^{57}$ Alternately, one can conceive of the impetus to empire as particularistic, housed in the aspirations of individual leaders, and thus more stuff of historical and biographical research than of social science. We view the preference for territorial aggression as a variable driven by environmental conditions that can recur or trend over time.

A second aspect of military innovation involves specialization. Armies can be used to fight and win wars against other armies, or to control the populations and territories of subject

(F'note continued)

State', Journal of Economic History, 33 (1973), 203-21; Frank Tallett, War and Society in Early Modern Europe, 1495-1715 (London: Routledge, 1997); David B. Abernethy, The Dynamics of Global Dominance: European Overseas Empires, 1415-1980 (New Haven, Conn.: Yale University Press, 2002).

${ }^{50}$ See, for example, Immanuel Wallerstein, The Modern World-System II: Mercantilism and the Consolidation of the European World-Economy, 1600-1750 (New York: Academic Press, 1980); Eric Hobsbawm, The Age of Empire, 1875-1914 (New York: Pantheon Books, 1987); Charles Tilly, Coercion, Capital, and European States (Cambridge, Mass.: Blackwell, 1992); Paul Schroeder, The Transformation of European Politics, 1763-1848 (New York: Clarendon Press, 1994).

${ }^{51}$ See, for example, Brian Downing, The Military Revolution and Political Change (Princeton, N.J.: Princeton University Press, 1992); Clifford Rogers, ed., The Military Revolution Debate: Readings on the Military Transformation of Early Modern Europe (Boulder, Colo.: Westview, 1995); Parker, The Military Revolution; Jordan Boyd-Graber, Only in Europe? The Economic and Military Foundations of European World Empires (Princeton, N.J.: Princeton University Press, 2004). Thompson contrasts demand side arguments with the supply side (the ease of conquest); see William R. Thompson, 'The Military Superiority Thesis and the Ascendancy of Western Eurasia in the World System', Journal of World History, 10 (1999), 143-78.

${ }^{52}$ Niall Ferguson, The Cash Nexus: Money and Power in the Modern World, 1700-2000 (New York: Basic Books, 2002); Jan Glete, War and the State in Early Modern Europe: Spain, the Dutch Republic, and Sweden as Fiscal-Military States, 1500-1660 (London: Routledge, 2002).

${ }^{53}$ Hendrik Spruyt, The Sovereign State and its Competitors: An Analysis of Systems Change (Princeton, N.J.: Princeton University Press, 1994).

${ }^{54}$ On the origins of Western military advantage, see John Lynn, 'The Evolution of Army Style in the Modern West, 800-2000', International History Review, 18 (1996), 505-45; William R. Thompson, 'A Test of a Theory of Co-Evolution in War: Lengthening the Western Eurasian Military Trajectory', International History Review, 28 (2006), 473-503.

${ }_{55}$ Gibbon, The Decline and Fall of the Roman Empire; Kennedy, Rise and Fall of the Great Powers.

${ }^{56}$ Rasler and Thompson, 'Global Wars, Public Debts, and the Long Cycle'; Kalevi J. Holsti, Peace and War: Armed Conflicts and International Order, 1648-1989 (Cambridge: Cambridge University Press, 1991).

${ }^{57}$ Hans J. Morgenthau, Politics among Nations: The Struggle for Power and Peace (New York: Knopf, 1948); John J. Mearsheimer, The Tragedy of Great Power Politics (New York: W. W. Norton, 2001). 
places. Winning at war involves massing military power against critical elements of an opposing force. ${ }^{58}$ Controlling civilian populations involves exerting limited force in many places at once. Innovations in military technology presumably influence the classic elements of firepower, mobility and protection. ${ }^{59}$ While the last two elements increase the ability of a military force of a given size to exert combat power and to control a populated space, the first factor leads optimal force structure in different directions. Heavy (strategic) bombers and missile cruisers are ineffective tools for crowd control. The logic of conventional war increasingly demands relatively large allocations of capital. In contrast, the logic of conquest and control calls for 'old fashioned' labour-intensive force structures - many soldiers with relatively little mechanization. The divergence of optimal force structures should mean that sophisticated capital-intensive militaries, armies that tend to win the wars they fight, should be less and less effective as occupiers. To the degree that the determinants of battlefield and colonial effectiveness differ, and to the extent that resources available to the military are finite, nations contemplating colonizing another country must choose between a military that is optimized for conventional combat, and a force structure intended primarily for occupation.

\section{Economic Development: When Empire Pays, and When It Does Not}

A central debate in the study of imperialism is over how much nations profited from empire. ${ }^{60}$ While a number of studies provide evidence that colonies could be profitable, at least over certain periods, ${ }^{61}$ scholars remain divided in their reading of the 'balance sheet' of empire. ${ }^{62}$ This debate is instrumental to our objectives in explaining the basic imperial dynamic, however. We note simply that colonial conquest offered a perceived economic benefit to key constituencies or decision makers. Subsequently, the value of empire declined. If colonial holdings were never profitable (we doubt this), then rising costs of control, or declining benefits from markets or resources would eventually make clinging to empire prohibitive. Alternately, if empire was never a net drain on the imperial exchequer (we doubt this too), then plummeting profits must still weaken the forces of

58 Baron Antoine Henri de Jomini, The Art of War (Westport, Conn.: Greenwood, 1971 [1838]).

59 Basil Henry Liddell Hart, The Strategy of Indirect Approach (London: Faber \& Faber, 1946).

${ }^{60}$ Peter Liberman, Does Conquest Pay? The Exploitation of Occupied Industrial Societies (Princeton. N.J.: Princeton University Press, 1996); Stephen Brooks, 'The Globalization of Production and the Changing Benefits of Conquest', Journal of Conflict Resolution, 43 (1999), 646-70; Stephen Brooks, Producing Security: Multinational Corporations, Globalization \& the Changing Calculus of Conflict (Princeton, N.J.: Princeton University Press, 2005); Niall Ferguson, Empire: The Rise and Demise of the British World Order and the Lessons for Global Power (New York: Basic Books, 2003).

${ }^{6}$ David K. Fieldhouse, Economics and Empire 1830-1914 (Ithaca, N.Y.: Cornell University Press, 1973); Richard D. Wolff, The Economics of Colonialism: Britain and Kenya, 1870-1930 (New Haven, Conn.: Yale University Press, 1974); Jacques Marseille, Empire coloniale et capitalisme francaise. Histoire d'un divorce (Paris: Albin Michel, 1984); Avner Offer, 'The British Empire, 1870-1914: A Waste of Money?' Economic History Review, 46 (1993), 215-38; Niall Ferguson, 'The British Empire Revised: The Costs and Benefits of "Anglobalization", Historically Speaking, 4 (2003), 21-7.

${ }^{62}$ See, for example, Lance E. Davis and Robert Huttenback, 'The Political Economy of British Imperialism: Measures of Benefits and Support', Journal of Economic History, 42 (1982), 119-30; Lance E. Davis and Robert Huttenback, Mammon and the Pursuit of Empire: The Political Economy of British Imperialism, 1860-1912 (Cambridge: Cambridge University Press, 1986); Peter J. Cain and Anthony G. Hopkins, 'Gentlemanly Capitalism and British Expansion Overseas II: New Imperialism, 1850-1945', Economic History Review, 40 (1987), 1-26; Cain and Hopkins, British Imperialism; Andrew Porter, 'The Balance Sheet of Empire, 1850-1914', Historical Journal, 31 (1988), 685-99; Patrick O'Brien, 'The Costs and Benefits of British Imperialism, 1846-1914', Past and Present, 120 (1988), 163-200. 
colonialism and embolden opponents. Social forces within the metropolis (i.e. democracy) or in the colony (i.e. nationalism) could also have tipped the balance sheet, as we discuss later. The critical issue, which appears to be widely accepted, is that the economic benefits of empire declined over time. ${ }^{63}$

Nations, like firms or individuals, must address their wants through some combination of production, purchase and theft. ${ }^{64}$ Stealing is appealing when taking is more lucrative than making or trading. ${ }^{65}$ Theft can be preferred to purchase or production when the technology of stealing (appropriation) is relatively advanced, when the inputs to theft are relatively abundant, and when that which is taken is relatively valuable. Within borders, muggings and other property crimes tend to be committed by unemployed or unskilled labour. ${ }^{66}$ Governments attempt to reduce the appeal of private theft by limiting access to the technology of appropriation (regulating firearms, explosives, locksmiths, etc.) by improving the productivity of non-appropriative labour (schools, vocational training), or by reducing the expected benefits of theft (police and prisons). ${ }^{67}$

In contrast, the international system lacks some of the tools available domestically to discourage appropriation. ${ }^{68}$ Across national borders, governments or populations seek to prevent aggression by making conquest expensive (defence) or occupation unprofitable (nationalism, 'scorched earth' policies). Countries cannot much alter the productivity of foreign labour, however, and typically nations control their own appropriative technology. International incentives for choosing production over predation thus depend heavily on environmental conditions, and on exogenous change. ${ }^{69}$ If, for example, labour productivity rises in countries with the best appropriative technology, or if labour becomes scarce in these economies, while capital abundance drives down returns on appropriated capital, then countries capable of conquest will no longer covet colonial holdings, though these countries may continue to use force in a punitive manner for other political (policy) reasons. ${ }^{70}$

The question of whether to trade or take is one civilizations have confronted throughout history. ${ }^{71}$ Indeed, the two processes are linked. Vikings, the marauders of feudal Europe, were

63 Doyle, Empires.

${ }^{64}$ Charles Tilly, 'War Making and State Making as Organized Crime', in Peter Evans, Dietrich Rueschemeyer and Theda Skocpol, eds, Bringing the State Back In (Cambridge: Cambridge University Press, 1985), 169-87; Jack Hirshleifer, 'Conflict and Rent-seeking Success Functions: Ratio vs. Difference Models of Relative Success', Public Choice, 63 (1989), 101-12.

65 Mancur Olson, 'Dictatorship, Democracy, and Development', American Political Science Review, 87 (1993), 567-76.

66 Paul Strasburg, Violent Delinquents: A Report to the Ford Foundation from the Vera Institute of Justice (New York: Monarch Press, 1978); Mercer L. Sullivan, Getting Paid: Youth Crime and Work in the Inner City (Ithaca, N.Y.: Cornell University Press, 1989).

${ }^{67}$ Gary S. Becker, 'Crime and Punishment: An Economic Approach', Journal of Political Economy, 76 (1968), 169-217; Pablo Fajnzylber, Daniel Lederman and Norman Loayza, 'Crime and Victimization: An Economic Perspective', Economia, 1 (2000), 219-302.

${ }^{68}$ Joseph M. Grieco, 'Anarchy and the Limits of Cooperation: A Realist Critique of the Newest Liberal Institutionalism', International Organization, 42 (1988), 485-507; Lake, 'Anarchy, Hierarchy, and the Variety of International Institutions'.

69 Jack Hirshleifer, 'Economics and Biology: Evolution, Selection, and the Economic Principle', American Economic Review, 68 (1978), 238-43; Jack Hirshleifer, The Dark Side of the Force: Economic Foundations of Conflict Theory (New York: Cambridge University Press, 2001).

${ }^{70}$ Erik Gartzke and Dominic Rohner, 'To Conquer or Compel: War, Peace, and Economic Development' (Working Papers, University of California-San Diego, 2010).

71 Kenneth R. Andrews, Trade, Plunder and Settlement: Maritime Enterprise and the Genesis of the British Empire, 1480-1630 (Cambridge: Cambridge University Press, 1984). 
also the chief merchants of the era. ${ }^{72}$ After robbing the churches and great houses, they often established trading posts where less lucrative goods were bought and sold. ${ }^{73}$ Bank robbers often have bank accounts, while mobsters and petty criminals rob one person in order to pay another. Identifying how nations profit from particular combinations of trade and theft is central to the logic of empire. ${ }^{74}$

\section{The Imperialists' Dilemma: 'Mercantilism Made Me Do It'}

Imperialism creates an opportunity for states to engage in anti-competitive economic behaviour. ${ }^{75}$ The metropolis is in a position to determine whether trade will be allowed with third parties. ${ }^{76}$ These incentives extend beyond the dependencies of any imperial power when vertical integration restricts the growth of non-imperialist states. Barriers to market entry and to raw materials in foreign colonies encourage nations to seek their own colonies and to adopt mercantilist policies.

Prisoner's dilemma beggar-thy-neighbour colonial policies ensured that industrializing states sought colonial holdings to gain access to markets and resources. As key imperial powers chose to prevent other nations from trading in their colonial hinterlands, nations experiencing follow-on industrialization were forced to choose between limited growth and entry into empire. The mad rush to conquer the remaining unclaimed portions of the globe followed, not so much because every property was profitable, but because staying home ensured that possible future profits would never arise. The process of territorial 'crowding out' reversed itself once the predominant power no longer sought markets through colonial occupation, but instead used its leverage to open access.

Preliminary attempts by the United States to acquire colonies suggest that moral opposition to empire could be contained. ${ }^{77}$ Instead, later industrialization and large internal markets gave the United States a comparative advantage in free trade, while colonial expansion threatened war with Europe. ${ }^{78}$

${ }^{72}$ Karl W. Deutsch, 'Medieval Unity and the Economic Conditions for an International Civilization', Canadian Journal of Economics and Political Science, 10 (1944), 18-35.

${ }^{73}$ P. H. Sawyer, The Age of the Vikings (New York: St. Martin's, 1972); Gwyn Jones, A History of the Vikings (New York: Oxford University Press, 1984); Peter Kurrild-Klitgaard and Gert Tinggaard Svendsen, 'Rational Bandits: Plunder, Public Goods, and the Vikings', Public Choice, 117 (2003), $255-72$.

${ }^{74}$ Other factors, such as the symbolic value of territory (Tanisha Fazal, 'The Informalization of Interstate War' (paper presented at the Annual Meeting of the International Studies Association, San Diego, 2006), or geopolitical concerns (Nicholas J. Spykman, 'Frontiers, Security, and International Organization', Geographical Review, 32 (1942), 436-47; Nicholas J. Spykman, The Geography of the Peace (New York: Harcourt, Brace \& Co., 1944)), also influence the logic of empire. Yet empire is an extremely expensive pastime if it does not pay.

75 Jacob Viner, 'Power vs. Plenty as Objectives of Statecraft in the Seventeenth and Eighteenth Centuries', World Politics, 1 (1948), 1-29.

76 See, for example, Andrew Porter, European Imperialism, 1860-1914 (London: Macmillan, 1994); Judith B. Williams, British Commercial Policy and Trade Expansion, 1750-1850 (Oxford: Clarendon Press, 1972); Douglas Irwin, 'Mercantilism as Strategic Trade Policy: The Anglo-Dutch Rivalry for the East India Trade', Journal of Political Economy, 99 (1991), 1296-314; J. R. Ward, 'The Industrial Revolution and British Imperialism, 1750-1850', Economic History Review, 47 (1994), 44-65.

77 Mahan, The Influence of Sea Power on History, 1660-1783; Walter LaFeber, The New Empire: An Interpretation of American Expansion (Ithaca, N.Y.: Cornell University Press, 1963).

78 Richard Van Alstyne, The Rising American Empire (New York: Oxford University Press, 1960); Fareed Zakaria, From Wealth to Power: The Unusual Origins of America's World Role (Princeton, N.J.: Princeton University Press, 1998). 


\section{MODELLING IMPERIALISM}

We construct three main versions of a game-theoretic model of imperialism: a basic model of the effects of power, technology and economic development, a second model of domestic political liberalization and a third model that examines the role of system effects (mercantilism) in perpetuating empire. Supply-side arguments (nationalism, colonial populations) are modelled by varying the cost of appropriation. Additional treatments (the size of empire, insurgency) appear in two appendices. ${ }^{79}$ We begin with two actors $(N, S)$ that represent tribal groups, countries or regions of the world.

\section{The Basic Model}

We can think of the potential for colonization as 'lumpy'. A critical mass of fighting effectiveness and labour is necessary before a state can achieve any result. Warships and adventurers were needed before Europe could discover, and then conquer, the New World. Even neighbouring states must acquire some minimal level of capabilities to engage in territorial aggression. Appropriative activities thus only occur if the fighting effectiveness $\rho$ is higher than some arbitrary level $\hat{\rho}$. Formally, the restriction $\rho>\hat{\rho}$ ensures that a state projects power only when the threshold has been exceeded.

The production functions for actors $N$ and $S$ are displayed as Equations 1 and 2 below:

$$
\begin{aligned}
& y_{N}=\alpha L_{N}^{a} K_{N}^{b} \\
& y_{S}=\beta L_{S}^{c} K_{S}^{d},
\end{aligned}
$$

where $y=$ production output, $L=$ labour allocated to domestic production, $K=$ physical capital and land stock, $\alpha, \beta=$ total factor productivities, and where $a, b, c, d=$ exogenous parameters.

These production functions take the standard Cobb-Douglas form, where output depends on the two factors of production, capital $K$ and labour $L$, which are complements and are subject to decreasing returns (i.e. $a<1, b<1, c<1, d<1$ ). Actors also have a time endowment normalized to 1 and choose a proportion of time to allocate to production and to appropriation or defence:

$$
1=L_{i}+F_{i}+D_{i}
$$

where $F=$ time devoted to appropriation, $D=$ time used for defence, and where $i \in[N, S]$.

Imagine that $N$ develops a technological advantage. Europe's historical turning point began in the late feudal period when ideas and technology from the Muslim world diffused through Europe. ${ }^{80}$ At this stage, neither $N$ nor $S$ has reached the technological threshold for overseas conquest $\left(\rho_{S}<\rho_{N}<\hat{\rho}\right)$. By the fifteenth century, however, $N$ reaches the threshold, while $S$ does not, $\rho_{S}<\hat{\rho}<\rho_{N}$.

In the age of imperialism, $\rho_{S}<\hat{\rho}$. $S$ cannot colonize $N$. Accordingly, $S$ always chooses $F_{S}=0$. Thus, the time constraint of $S$ becomes $L_{S}+D_{S}=1$. Since $N$ will not be attacked by $S, N$ chooses $D_{N}=0$ and its time constraint becomes $L_{N}+F_{N}=1$. Thus, there is asymmetry in the incentive structure of the two players. This simplifies the analysis and reflects historical conditions.

\footnotetext{
79 All appendices are available online at: http://www.journals.cambridge.org/jps.

${ }^{80}$ Bernard Lewis, The Muslim Discovery of Europe (New York: W. W. Norton, 1982); Bernard Lewis, Cultures in Conflict: Christians, Muslims, and Jews in the Age of Discovery (New York: Oxford University Press, 1995).
} 
Colonizing an opponent entails appropriating land and physical capital, assets that are valuable but can either be bought or stolen. The prospects of colonization are endogenous in our framework and depend on the fighting efforts of $N$ and $S$. We first discuss the potential corner solutions where one or both actors select zero fighting effort. Clearly, when $F_{N}=0$, no colonization takes place. In this case, there is no fighting and both actors just receive their own domestic production: $N$ receives the entire $y_{N}$, and $S$ the entire $y_{S}$. Further, if $N$ makes a positive appropriation effort $F_{N}>0$, but $S$ fails to defend itself $D_{S}=0$, we assume that $N$ captures the whole production of both actors. Note, however, that in equilibrium we never observe $F_{N}>0$ and $D_{S}=0$, because $S$ would always be better off selecting a positive defence level (as we discuss further below).

We next introduce the payoff functions for interior solutions when both players select positive fighting efforts, $F_{N}>0$ and $D_{S}>0$. We assume that the part of the land and physical capital in $S$ captured by $N$ depends on the difference between the fighting efforts of $N$ and $S$. When $F_{N}$ is much larger than $D_{S}$, we assume that on average $N$ captures a large part of $K_{S}$, while $N$ captures an intermediate portion of $K_{S}$ when $F_{N}$ and $D_{S}$ are of similar size, and so on. Use of a linear appropriation technology allows for a tractable model with production functions with decreasing returns to labour and capital (i.e. Cobb-Douglas). ${ }^{81}$ As actors trade off concave production gains with linear appropriation gains, there is always a unique interior optimum involving positive fighting levels of both players. Formally, Equation 4 represents the payoff (utility) function for actor $N$ :

$$
V_{N}=\alpha L_{N}^{a} K_{N}^{b}+\left[\frac{1}{2}+\theta\left(\rho_{N} F_{N}-\rho_{S} D_{S}\right)\right] K_{S},
$$

where $\rho=$ fighting effectiveness or latent power $(0<\rho<1)$, and $\theta=\mathrm{a}$ parameter $(0<\theta<0.5)$.

$N$ 's payoff equals its production output $\left(\alpha L_{N}^{a} K_{N}^{b}\right)$, plus what capital and territory it 'steals' from $S$. The term $\left[\frac{1}{2}+\theta\left(\rho_{N} F_{N}-\rho_{S} D_{S}\right)\right]$ is the 'contest success function'. ${ }^{82}$ As mentioned above, the greater the appropriation effort of $N$, and the lower the defensive effort of $S$, the more capital and territory $N$ gains. The parameter $\theta$ refers to the decisiveness of the fighting effort. If $\theta=\frac{1}{2}$, fighting is perfectly effective in determining distribution, whereas if $\theta=0$, the time spent on fighting has no effect on the distribution of benefits. ${ }^{83}$ We also include a friction component to the fighting effort $(1-\rho)$. Improvements in military effectiveness or capabilities (higher $\rho$ ) make appropriation more efficient, which also means that $N$ has less to lose by fighting $S$.

We shall now look inside the 'black box' of fighting effectiveness or latent military power. It is important to distinguish between the concepts of 'fighting effectiveness' and 'fighting technology'. While the first concept refers to how successful a state is at appropriating or controlling colonial holdings for a given level of fighting effort, the second refers to the capital intensiveness of an army (i.e. the capital:labour ratio of defence or appropriation). Development leads to capital accumulation and results in the

${ }^{81}$ Several studies use similar linear appropriation technologies. See, for example, Dominic Rohner, 'Beach Holiday in Bali or East Timor? Why Conflict Can Lead to Under- and Overexploitation of Natural Resources', Economics Letters, 92 (2006), 113-17.

${ }^{82}$ Jack Hirshleifer, 'Conflict and Rent-seeking Success Functions: Ratio vs. Difference Models of Relative Success', Public Choice, 63 (1989), 101-12.

${ }^{83}$ Rohner, 'Beach Holiday in Bali or East Timor?' 
substitution of capital for labour in both civilian production and the military. This substitution (an increase in fighting technology) is usually less than one to one. Hence, it makes sense to think of fighting technology as a concave, increasing function of total factor productivity. This higher capital-intensity of the army may or may not lead to greater fighting effectiveness (although if it does improve fighting effectiveness, we can assume that this rise is also less than one to one). While it is reasonable to think that military technology is very important for conquest (e.g. ships are crucial), for the control of the colonized populations labour may matter more than capital, and capital-intensive high-tech armies may not perform as well.

Given this, fighting effectiveness, $\rho_{N}$ and $\rho_{S}$, respectively, can be seen as a concave function of the total national factor productivity denoted by $\alpha$ and $\beta$. We assume that $\rho_{N}$ is a concave function of $\alpha$, and that $\rho_{S}$ is a concave function of $\beta$, as increases in the general technology level of a society result in less than proportional increases (or even decreases) in fighting effectiveness. Technology requires military specialization, which optimizes force structures for battlefields versus riot control or counterinsurgency. ${ }^{84}$ Factors such as muscle power and the morale of personnel are also effectively fixed; thus, doubling a country's weapons less than doubles the country's military strength. A functional form that reflects this reasoning is $\rho=k \alpha^{\mu}$, where $k=$ constant, $\mu<1 .^{85}$

Introducing the time constraint $L_{N}+F_{N}=1$ into $N$ 's payoff function and solving for first order conditions, we obtain $N$ 's optimal level of $L_{N}$ :

$$
L_{N}^{*}=\left(\frac{\alpha a K_{N}^{b}}{\theta \rho_{N} K_{S}}\right)^{\frac{1}{1-a}},
$$

where $L_{N}^{*}=$ the optimal level of $L_{N}$, and other variables or parameters are as described. For simplicity, we will focus on parameter values for $0<L_{N}^{*}<1$, which guarantees that there always exists an interior solution, and which is the most interesting case for our research question.

Note that this interior $L_{N}^{*}$ is the unique solution in the basic framework. An equilibrium of no appropriation and no defence would not be sustainable as $N$ would always have incentives to deviate and choose some positive level of appropriation. Similarly, for positive appropriation efforts of $N, S$ would also always have incentives to select positive levels of defensive activities.

$N$ 's optimal production level increases with total factor productivity, and decreases with fighting effectiveness (its military power or capabilities). Productivity increases encourage domestic production, while greater military power makes it more appealing to appropriate (steal) land or capital from $S$. The net effect of production technology on labour time is positive, however, as productivity increases yield less than proportional increases, or even decreases, in fighting effectiveness.

The payoff function for actor $S$ follows a similar logic. $S$ can either invest time into production or defence. Its payoff simply corresponds to its economic output that is

\footnotetext{
84 Jeremy Black, War: Past, Present and Future (New York: St. Martin's, 2000). Few states are able to integrate military technologies effectively, while forces optimized for conventional war are at a comparative disadvantage in asymmetric conflicts. See Stephen Biddle, 'Assessing Theories of Future Warfare', Security Studies, 88 (1998), 1-74.

${ }^{85}$ One could also imagine that fighting effectiveness decays in the distance between metropolis and colony: $\partial \rho / \partial d<0$, where $d=$ distance, or assumes a specific function, as in the gravity model: $(1-\rho)=\omega d^{2}$, where $\omega$ is exogenous.
} 


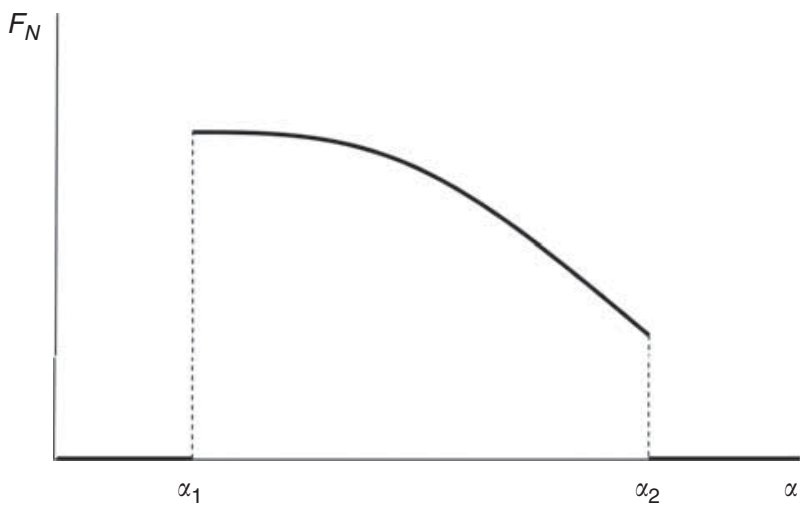

Fig. 1. The level of colonization effort chosen by $N$

produced using its remaining capital (the part that has not been appropriated by $N$ ) and its time devoted to labour. Formally:

$$
V_{S}=\beta L_{S}^{c}\left\{\left[\frac{1}{2}+\theta\left(\rho_{S} D_{S}-\rho_{N} F_{N}\right)\right] K_{S}\right\}^{d} .
$$

The part of $K_{S}$ controlled by $N, \frac{1}{2}+\theta\left(\rho_{N} F_{N}-\rho_{S} D_{S}\right)$, and the portion owned by $S$, $\frac{1}{2}+\theta\left(\rho_{S} D_{S}-\rho_{N} F_{N}\right)$, sum to 1 . Introducing the time constraints, $L_{S}+D_{S}=1$ and $L_{N}+F_{N}=1$, and setting the first derivative of Equation 6 with respect to $L_{S}$ equal to zero, we obtain $S$ 's reaction function:

$$
L_{S}^{*}=\frac{c\left[\frac{1}{2}+\theta\left(\rho_{S}-\rho_{N}\left(1-L_{N}^{*}\right)\right)\right]}{\theta \rho_{S}(c+d)},
$$

where $L_{S}^{*}=$ the optimal level of $L_{S}$, and other variables or parameters are as described. As expected, $S$ 's defence effort increases (lower $L_{S}$ ) in $N$ 's colonization effort (lower $L_{N}$ ).

The first and second waves of European colonization (Latin America, Asia) can be explained using the basic model outlined above. The third wave of colonization involves system effects discussed below. As illustrated in Figure 1, threshold conditions initially constrain territorial empire. The level where domestic production technology reaches this first threshold (such that $\rho_{N}>\hat{\rho}$ ) is labelled $\alpha_{1}$. Incentives for empire then decay gradually with increasing productivity. Finally, colonialism collapses when development reaches $\alpha_{2}$. The rapidity in the fall of colonialism can be accounted for by fixed costs (see Appendix A) ${ }^{86}$ or by democratization (see the next subsection).

Figure 1 reveals that the relationship between productivity (economic development) and efforts to acquire colonies is non-linear. Initially, development increases the ability to plunder, encouraging the pursuit of empire once the threshold capabilities are achieved. As productivity continues to increase, however, and capital accumulates, incentives to appropriate decline ( $N$ prefers making to taking).

HYPOTHESIS 1. The effect of economic development on territorial empire should be strictly concave, first increasing, and then later decreasing the likelihood of a country possessing colonial holdings.

${ }^{86}$ All appendices are available online at: http://www.journals.cambridge.org/jps. 
Unsurprisingly, military power probably makes empire more attractive. While power is a somewhat ambiguous term - referring alternatively to the potential to influence and to the act of influencing - there are reasonably direct empirical analogues for the notion of capable or effective military power. We thus hypothesize that capability should increase the appeal of empire.

HYPOTHESIS 2. Increasing military effectiveness (greater capabilities/latent power) should make countries more likely to hold colonies.

Fighting technology can also be measured empirically, as we discuss in the empirical section below. The model does not tell us directly whether fighting technology leads to more or less territorial empire. However, we have speculated that capital-intensive armies do a poorer job at controlling subject populations. As nations accumulate capital, it is substituted for labour in both civilian and military (appropriative) production technologies. If, in addition, optimal force structures for winning wars and for plundering populations diverge with development, then we expect that the capital-intensiveness of an army is negatively associated with maintaining colonies.

HYPOTHESIS 3. Increasing fighting technology (more capital-intensive military) should tend to discourage territorial empire.

\section{Political Liberalization}

Some scholars have suggested that European democratization contributed to decolonization. ${ }^{87}$ In this section, we examine the possibility that political liberalization discourages territorial empire.

Appropriation and production decisions do not result from a plebiscite. Leaders and key political supporters may receive intense benefits from appropriation, even if empire is not socially optimal for the country as a whole. In the model below, the task of the government is to choose and impose a unified level of labour $L$, which can be more or less close to socially optimal levels, but which is eventually adopted by both the population and the elite. This politically optimal level is found by optimizing Equation 8, the payoff function for the government of $N$, with respect to labour $L$.

$$
V_{G N}=\varphi V_{P N}+(1-\varphi) V_{E N}-\zeta\left(V_{E N}-V_{P N}\right),
$$

where $V_{G N}=$ payoff function of the government of $N, \varphi=$ relative weight attributed to the collective payoff function of the population, $V_{P N}=$ payoff function of the population of $N$, $V_{E N}=$ payoff function of the ruling elite of $N, \zeta$ is the parameter capturing the costs of political instability.

The government cares about the payoff function of the population, as the leader wants to stay in power. However, for similar reasons, it also cares about the payoff function of the ruling elite. The relative weight of the two payoff functions depends on the level of democratization $(M)$. As a regime becomes more democratic, the weight attributed by the leader to the utility of the population increases, $\partial \varphi / \partial M>0$. A complete theory of democratization would endogenize $\varphi$ in terms of other parameters or variables. Making $\varphi$ exogenous serves our purposes here and simplifies exposition.

87 See, for example, Kahler, Decolonization in Britain and France; Snyder, Myths of Empire; David Strang, 'The Inner Incompatibility of Empire and Nation: Popular Sovereignty and Decolonization', Sociological Perspectives, 35 (1992), 367-84. 
We also model the risk of political instability due to distributive conflicts that occur if relative payoffs of $V_{E N}$ and $V_{P N}$ are quite different. This is captured by the term $\zeta\left(V_{E N}-V_{P N}\right)$, which we can represent as $\zeta\left(V_{E N}-V_{P N}\right)$ rather than in absolute values, $\zeta\left|V_{E N}-V_{P N}\right|$, assuming conventionally that elites are richer, more productive and can more easily capture rents from colonies: $\alpha_{E N}>\alpha_{P N}, K_{E N}>K_{P N}, \rho_{E N}>\rho_{P N}$. Elites have better access to business relationships, ${ }^{88}$ and to political power, ${ }^{89}$ extracting heavy rents from the country's colonial policies. If elites benefited from empire at the expense of the larger population, ${ }^{90}$ or if democratization in Europe allowed moral sentiment to hold sway, ${ }^{91}$ then democracy should lead to a decline in territorial empire. ${ }^{92}$

Given that the level of labour is imposed by the government, $L=L_{E N}=L_{P N}$, it follows from Equation 4 that $V_{E N}>V_{P N}$, if the assumptions $\alpha_{E N}>\alpha_{P N}, K_{E N}>K_{P N}, \rho_{E N}>\rho_{P N}$ hold and if $a_{E N}$ and $a_{P N}$, as well as $b_{E N}$ and $b_{P N}$, are of a similar magnitude. Introducing Equation 4 for both the elite and the population into the government's payoff function (Equation 8), we obtain Equation 9. The new variables $x, y$ and $z$ are introduced to facilitate interpretation of the results. For the purposes of illustration only, we further assume that $a=a_{E N}=a_{P N}$ and $b=b_{E N}=b_{P N}$.

$$
\begin{aligned}
V_{G N}= & \varphi\left(x_{P N} L^{a}-y_{P N} L+z_{P N}\right)+(1-\varphi)\left(x_{E N} L^{a}-y_{E N} L+z_{E N}\right) \\
& -\zeta\left(x_{E N} L^{a}-y_{E N} L+z_{E N}-\left(x_{P N} L^{a}-y_{P N} L+z_{P N}\right)\right),
\end{aligned}
$$

where $x_{P N}=\alpha_{P N} K_{P N}^{b}, y_{P N}=\theta \rho_{P N} K_{S}, z_{P N}=\left[\frac{1}{2}+\theta\left(\rho_{P N}-\rho_{S} D_{S}\right)\right] K_{S}, x_{E N}=\alpha_{E N} K_{E N}^{b}$, $y_{E N}=\theta \rho_{E N} K_{S}$, and where $z_{E N}=\left[\frac{1}{2}+\theta\left(\rho_{E N}-\rho_{S} D_{S}\right)\right] K_{S}$.

Taking first order conditions, we obtain Equation 10, the optimal labour level set by government:

$$
\begin{aligned}
L_{G N}^{*} & =\left[\frac{a\left((\varphi+\zeta) x_{P N}+(1-\varphi-\zeta) x_{E N}\right)}{(\varphi+\zeta) y_{P N}+(1-\varphi-\zeta) y_{E N}}\right]^{\frac{1}{1-a}} \\
& =\left[\frac{a\left((\varphi+\zeta) \alpha_{P N} K_{P N}^{b}+(1-\varphi-\zeta) \alpha_{E N} K_{E N}^{b}\right)}{(\varphi+\zeta) \theta \rho_{P N} K_{S}+(1-\varphi-\zeta) \theta \rho_{E N} K_{S}}\right]^{\frac{1}{1-a}}
\end{aligned}
$$

Note that for $x_{P N}=x_{E N}$ the result for $L_{G N}^{*}$ is just identical to the result in Equation 5: $L_{G N}^{*}=L_{N}^{*}=\left(\frac{\alpha a K_{N}^{b}}{\theta \rho_{N} K_{S}}\right)^{\frac{1}{1-a}}$. It is also interesting to see that political instability increases

${ }^{88}$ Cain and Hopkins, British Imperialism.

${ }^{89}$ Snyder, Myths of Empire.

90 Daron Acemoglu, 'Why Not a Political Coase Theorem? Social Conflict, Commitment and Politics', Journal of Comparative Economics, 31 (2003), 620-52; Mirjam E. Sørli, Nils Petter Gleditsch and Håvard Strand, 'Why Is There So Much Conflict in the Middle East?' Journal of Conflict Resolution, 49 (2005), $141-65$.

91 Robert Jackson, Quasi-States: Sovereignty, International Relations, and the Third World (New York: Cambridge University Press, 1990); Adam Watson, The Evolution of International Society: A Comparative Historical Analysis (London: Routledge, 1992).

${ }^{92}$ For claims that democracies are imperialistic, see Michael Haas, 'When Democracies Fight One Another, Just What is the Punishment for Disobeying the Law?'(paper presented at the Annual Meetings of the American Political Science Association, Chicago, 1995); Galtung, The Decline and Fall of Empires; Errol A. Henderson, Democracy and War: The End of an Illusion (Boulder, Colo.: Lynne Rienner, 2002); Spruyt, Ending Empire. 
the weight attributed to the population's payoff. In fact, increases in $\zeta$ have exactly the same effect as increases in $\varphi$. By moving $L$ closer to the population's optimum, inequality between elite and population is reduced, which decreases the government's loss resulting from political turmoil.

Whether democratization (higher $\varphi$ ) leads to a higher or lower $L_{G N}^{*}$ depends on the relative size of $L_{E N}^{*}$ and $L_{P N}^{*}$, where

$$
L_{P N}^{*}=\left(\frac{\alpha_{P N} a K_{P N}^{b}}{\theta \rho_{P N} K_{S}}\right)^{\frac{1}{1-a}}=\left(\frac{a x_{P N}}{y_{P N}}\right)^{\frac{1}{1-a}} \text { and } L_{E N}^{*}=\left(\frac{\alpha_{E N} a K_{E N}^{b}}{\theta \rho_{E N} K_{S}}\right)^{\frac{1}{1-a}}=\left(\frac{a x_{E N}}{y_{E N}}\right)^{\frac{1}{1-a}} .
$$

Assuming that elites are richer $\left(K_{E N}>K_{P N}\right)$, and more productive $\left(\alpha_{E N}>\alpha_{P N}\right)$, implies that $x_{E N}>x_{P N}$. Assuming that elites extract more of the rents from colonies $\left(\rho_{E N}>\rho_{P N}\right)$ implies that $y_{E N}>y_{P N}$. Whether on the whole $L_{E N}^{*}$ is greater or smaller than $L_{P N}^{*}$ depends on the relative size of the wealth-productivity effect on the one hand $\left(x_{E N}\right.$ versus $\left.x_{P N}\right)$ and of the rent-extracting effect $\left(y_{E N}\right.$ versus $\left.y_{P N}\right)$ on the other. If the difference in wealth and productivity is large, but elites are much better at extracting rents $\left(y_{E N} \gg y_{P N}\right)$, then $L_{E N}^{*}<L_{P N}^{*}$. This implies that democratization (a larger $\varphi$ ) reduces colonization, as the greater weight of $L_{P N}^{*}$ increases $L_{G N}^{*}{ }^{93}$

Colonial holdings could have continued to profit elites even if they produced losses overall. Rapid decolonization can be explained by economic factors alone (see Appendix A), ${ }^{94}$ but political liberalization could also have played a role. We must rely on empirical assessment to determine what mix of factors triggered decolonization. Domestic politics suggests the following hypothesis:

HYPOTHESIS 4. Democracies should be less likely to possess (or to seek to acquire) colonies.

\section{Accounting for System Effects}

The logic of empire may be conditioned as well by system-level variables. The structure of the global economy is affected by the choices of multiple nations. While free markets are socially optimal, individual participants often have incentives to engage in anticompetitive policies, if able. ${ }^{95}$ Countries may pursue or perpetuate colonial holdings if other countries inhibit free trade or capital.

Parsimonious models explain particular relationships, while omitting others. Different models also reflect competing claims in the literature and allow us to compare the implications of different assumptions. We next relax the assumption of a single imperialist country, including two players $N_{1}$ and $N_{2}$, that compete over access to $S$. We use the Nash equilibrium solution concept to solve a game in which the two imperialist countries choose between producing $(L)$, and fighting $(F)$.

$$
L_{i}+F_{i}=1 \text {, with } i=N_{1}, N_{2} \text {. }
$$

93 Economic development results in higher values of $\alpha_{E N}, \alpha_{P N}, \rho_{E N}, \rho_{P N}$, which increases $x_{E N}, x_{P N}, y_{E N}$, $y_{P N}$, though not necessarily at the same rate. The net effect of democracy thus varies with time and development.

94 All appendices are available online at: http://www.journals.cambridge.org/jps.

95 John A. C. Conybeare, Trade Wars: The Theory and Practice of International Commercial Rivalry (New York: Columbia University Press, 1987). 
Equation 12 displays the payoff function of country $N_{1}$ ( $N_{2}$ 's payoff function is analogous):

$$
\begin{aligned}
V_{N_{1}}= & L_{N_{1}}\left(A+B\left[\frac{1}{2}+\psi\left(\rho_{N_{1}} F_{N_{1}}-\rho_{N_{2}} F_{N_{2}}\right)\right]\left(1-\lambda D_{S}\right)\right) \\
& +\left[\frac{1}{2}+\psi\left(\rho_{N_{1}} F_{N_{1}}-\rho_{N_{2}} F_{N_{2}}\right)\right]\left(1-\lambda D_{S}\right) K_{S},
\end{aligned}
$$

where $A=$ marginal productivity of labour, $B=$ potential marginal gains from trade, $\psi=$ parameter related to the decisiveness of the fighting effort (with $0<\psi \leq 0.5$ ), $\rho=N$ 's fighting effectiveness or power $(0<\rho<1)$, and $\lambda=\mathrm{a}$ parameter related to the defensive technology of player $S$.

Equation 12 has the same overall structure as Equation 4. However, since including a second colonial power increases model complexity, we simplify other aspects to keep the model tractable. ${ }^{96}$

The payoff for country $N_{1}$ is composed of three elements. First, there are returns on productive activities, which are increasing in parameter $A$. Secondly, there are gains from trade that increase in parameter $B$ and in the portion of country $S$ that is controlled by $N_{1},\left(\frac{1}{2}+\psi\left(\rho_{N_{1}} F_{N_{1}}-\rho_{N_{2}} F_{N_{2}}\right)\right)\left(1-\lambda D_{S}\right) .{ }^{97}$ Treating $S$ as divisible can be interpreted as the portion of the developing world controlled by a given imperialist power. Mercantilism attempts to restrict trade with a given colony to the colonial power. Thus, if one country $\left(N_{1}\right)$ acquired all of $S, N_{2}$ would not trade.

The portion of country $S$ that is colonized is represented by $\left(1-\lambda D_{S}\right)$. Given that the focus here is on the interaction between $N_{1}$ and $N_{2}$, we treat $D_{S}$ as exogenous. The part of this colonized fraction of $S$ that is controlled by $N_{1}$ and that can be used as an exclusive trade partner is specified by the difference-form contest success function $\left(\frac{1}{2}+\psi\left(\rho_{N_{1}} F_{N_{1}}-\rho_{N_{2}} F_{N_{2}}\right)\right)$. The parameter $\psi$ reflects how decisive fighting is in determining the division of the colony. If $\psi=0$, fighting does not affect the division of resources. For $\psi=0.5$, fighting is fully decisive. We assume that fighting has some strictly positive effect (i.e. $\psi>0$ ). The logic of this contest success function parallels the basic model. When $F_{N_{1}}$ is larger than $F_{N_{2}}, N_{1}$ receives a greater share of the colony, and vice versa.

The third component of country $N_{1}$ 's payoff is the portion of the value of the colony, $K_{S}$, that it captures through fighting. Fighting for colonies against rival imperialist powers results in a direct benefit, the portion of $K_{S}$ gained, and in an indirect benefit, the possibility of trade. The profit from appropriation must be balanced against productive income lost due to friction from conflict.

Introducing players' time constraints (11) into $N_{1}$ 's payoff function (12), we get Equation 13:

$$
\begin{aligned}
V_{N_{1}}= & L_{N_{1}}\left(A+B\left[\frac{1}{2}+\psi\left(\rho_{N_{1}}\left(1-L_{N_{1}}\right)-\rho_{N_{2}}\left(1-L_{N_{2}}\right)\right)\right]\left(1-\lambda D_{S}\right)\right) \\
& +\left[\frac{1}{2}+\psi\left(\rho_{N_{1}}\left(1-L_{N_{1}}\right)-\rho_{N_{2}}\left(1-L_{N_{2}}\right)\right)\right]\left(1-\lambda D_{S}\right) K_{S} .
\end{aligned}
$$

Setting the first derivative of equation (13) with respect to $L_{N_{1}}$ equal to zero and expressing the result in terms of $L_{N_{1}}$, we find the optimal value of $L_{N_{1}}$ displayed in the reaction function (14). The solution is analogous for player $N_{2}$. Note that these are the results for an interior solution. Corner solutions follow from the fact that neither variable

\footnotetext{
96 These simplifying assumptions are not critical to the main results of the model.

97 We again focus on the unique interior Nash Equilibrium with $F_{N_{1}}>0, F_{N_{2}}>0$.
} 


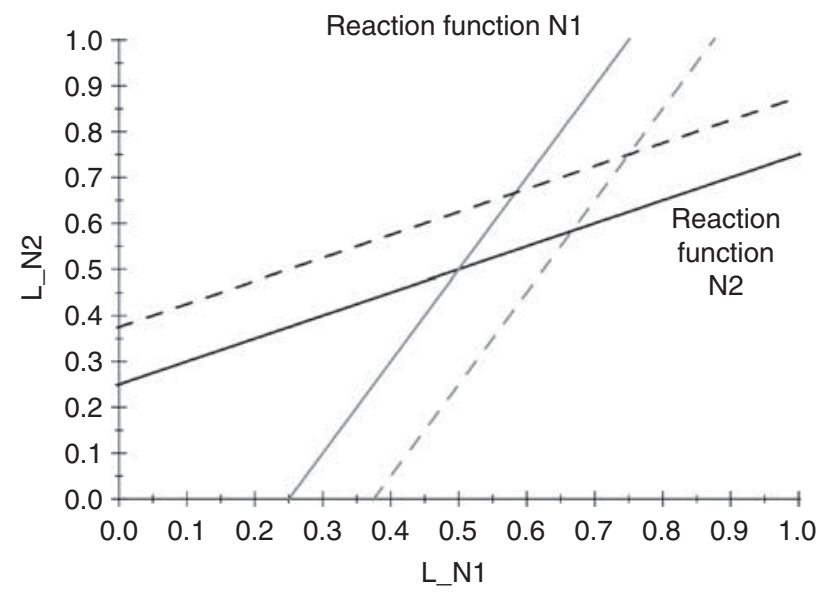

Fig. 2. The reaction functions of the countries $N_{1}$ and $N_{2}$

can become negative, $L_{N_{1}} \geq 0, F_{N_{1}} \geq 0$ :

$$
L_{N_{1}}^{*}=\frac{A+B\left(\frac{1}{2}+\psi\left(\rho_{N_{1}}-\rho_{N_{2}}\right)\right)\left(1-\lambda D_{S}\right)-\psi \rho_{N_{1}} K_{S}\left(1-\lambda D_{S}\right)}{2 B \rho_{N_{1}} \psi\left(1-\lambda D_{S}\right)}+\frac{\rho_{N_{2}} L_{N_{2}}^{*}}{2 \rho_{N_{1}}},
$$

where $L_{N_{1}}^{*}$, resp. $L_{N_{2}}^{*}$ are the optimal levels of $L_{N_{1}}$, resp. $L_{N_{2}}$.

According to Equation 14, the proportion of labour time $N_{1}$ devotes to production increases in its productivity $(A)$, and decreases with a more attractive target (higher $K_{S}$ ). These findings are both consistent with the basic model, but in addition, systemic competition now creates an 'imperialist race'. The more time $N_{2}$ spends on productive activities (higher $L_{N_{2}}$ ), the more time country $N_{1}$ devotes to production. Conversely, when country $N_{2}$ puts time effort into fighting, country $N_{1}$ does so also. Thus, colonization by one power induces imperialism in other states:

HYPOTHESIS 5. A country is more likely to hold colonies when the system contains many colonies.

The strategic interaction between the two imperialist countries $N_{1}$ and $N_{2}$ is illustrated in Figure 2. ${ }^{98}$ The grey (black) lines represent the reaction function of country $N_{1}\left(N_{2}\right)$. The solid (dashed) lines correspond to a case of low (high) productivity, $A=0.16(A=0.24)$. The Nash equilibrium for the solid lines is at $(0.5 ; 0.5)$, and is $(0.75 ; 0.75)$ for the dashed lines. The reaction functions for both countries are positively sloped, indicating that each country increases its production effort for increases in the productive effort of the other state. This also means that a state increases its colonization effort for increases in the colonial activity of the other power.

A slight extension of the systemic model helps to explain how the move from mercantilism to freer global markets helped to trigger rapid decolonization. Up to now, we have assumed that all gains from trade depend on the territorial control of trade partners (mercantilism). We can now allow that only a part $\gamma$ of the trade gains depends

98 The following parameter values are used for the solid lines (they are symmetrical for both players): $A=0.16, B=0.8, K_{S}=1, \psi=0.4, \rho_{N_{1}}=\rho_{N_{2}}=1, \lambda=0.5, D_{S}=0$. For the dotted lines we have $A=0.24$. 
on possession of colonies. The move from mercantilism to capitalism and freer trade is reflected by a gradual decrease in $\gamma .{ }^{99}$

We introduce the possibility of partially free trade by changing Equation 12 into Equation 12' below:

$$
\begin{gathered}
V_{N_{1}}=L_{N_{1}}\left(A+B(1-\gamma)+B \gamma\left[\frac{1}{2}+\psi\left(\rho_{N_{1}} F_{N_{1}}-\rho_{N_{2}} F_{N_{2}}\right)\right]\left(1-\lambda D_{S}\right)\right) \\
+\left[\frac{1}{2}+\psi\left(\rho_{N_{1}} F_{N_{1}}-\rho_{N_{2}} F_{N_{2}}\right)\right]\left(1-\lambda D_{S}\right) K_{S} .
\end{gathered}
$$

All variables are defined as before. The parameter $\gamma$ can be interpreted as the level of mercantilism. Naturally, the results for $\gamma=1$ are identical to the results presented above. By contrast, $\gamma=\varepsilon$ (where $\varepsilon$ is an infinitely small positive number) corresponds to a capitalist free trade system.

Introducing the time constraints (Equation 11) into Equation 12' and computing the first-order conditions, we get:

$$
L_{N_{1}}^{*}=\frac{A+B(1-\gamma)+B \gamma\left(\frac{1}{2}+\psi\left(\rho_{N_{1}}-\rho_{N_{2}}\right)\right)\left(1-\lambda D_{S}\right)-\psi \rho_{N_{1}} K_{S}\left(1-\lambda D_{S}\right)}{2 B \gamma \rho_{N_{1}} \psi\left(1-\lambda D_{S}\right)}+\frac{\rho_{N_{2}} L_{N_{2}}^{*}}{2 \rho_{N_{1}}} .
$$

We can evaluate the effect of mercantilism and capitalism on incentives for imperialism and decolonization by looking at the first derivative of $L_{N_{1}}$ with respect to $\gamma$. A negative first derivative implies that more capitalism (lower $\gamma$ ) increases the incentives to produce (higher $L_{N_{1}}$ ) and accordingly reduces the incentives to fight (lower $F_{N_{1}}$ ) to gain or retain control of foreign territory or markets. The first derivative of $L_{N_{1}}$ with respect to $\gamma$ becomes negative, if condition (15) holds:

$$
A+B>\psi \rho_{N_{1}} K_{S}\left(1-\lambda D_{S}\right) .
$$

Condition 15 holds when the gains from production $(A)$ and the gains from trade $(B)$ are each large relative to the product of $S$ 's capital endowment, the fighting effectiveness of $N_{1}$, and the pivotal nature of warfare. In the period after the Second World War, the steady decay of barriers to trade, the relative poverty of developing countries, as well as the rise of nationalist insurgency movements made colonialism less appealing. Changes in the global economy had by the early twentieth century created conditions in which the economics of colonies, as well as the vertical integration of production networks, was increasingly inefficient. Sources for raw materials proliferated. The ascendance of the United States as a hegemon further degraded the economic advantages of empire. ${ }^{100}$

Mercantilism can be proxied empirically as a situation where the hegemon holds many colonies.

HYPOTHESIS 6. A country is more likely to hold colonies when the hegemon has many colonies.

\footnotetext{
${ }^{99}$ With $\gamma$ in the denominator, the reaction function $\left(14^{\prime}\right)$ is undefined when $\gamma=0$. It makes sense to treat free trade as an absolute that is only approximated empirically (after multiple World Trade Organization rounds, trade is still not 'free').

100 William Roger Louis, Imperialism at Bay: The United States and the Decolonization of the British Empire 1941-45 (New York: Oxford University Press, 1987).
} 
Development started with agricultural societies, moved through mercantilism, to be followed by capitalism. We expect the effect of systemic development on colonial holdings to be non-linear.

HYPOTHESIS 7. The effect of systemic development on territorial empire should be strictly concave, first increasing, and then later decreasing the likelihood of a country possessing colonial holdings.

\section{RESEARCH DESIGN AND DATA}

While our theory applies to broad swaths of history, our empirical analysis is limited by data availability to the last two centuries (1816-1992). Our unit-of-analysis is the country year. We examine both dichotomous (presence or absence) and ordinal (count) indicators of colonialism/decolonization. Given a dichotomous dependent variable, we use the ReLogit estimator. ${ }^{101} \mathrm{We}$ use negative binomial regression to estimate the number of colonies a country holds. We correct for spatial dependence using Huber/White robust standard errors. Independent variables are lagged by one year to address endogeneity. We also include a set of spline variables to control for duration dependence. ${ }^{102}$ The descriptive statistics of all variables are displayed in Table 3.

\section{Dependent Variable}

The dichotomous and count versions of the dependent variable come from two sources. Strang provides a list of the start and end years for a large number of dependencies beginning in the late fifteenth century. ${ }^{103}$ Strang includes dependencies that are not under colonial domination and cases where political boundaries change over time. This could be a problem if dependencies operated under a different logic than colonies, or if dependencies experience reorganization, but not decolonization. These discrepancies are bound to weaken support for our claims. We also examine colony data generated by Ravlo et al. ${ }^{104}$ The authors use these data as an independent variable as part of a statistical analysis of their argument that democracies are less warlike towards former colonies.

\section{Independent Variables}

- Economic development: Given the need to cover substantial time periods before the mid-twentieth century, we adopt two variables widely used as proxies for per capita gross domestic product (GDP). ${ }^{105}$ (1) Energy Cons./Pop. comes from the COW

101 Gary King and Kangche Zeng, 'Explaining Rare Events in International Relations', International Organization, 55 (2001), 693-715; Gary King and Langche Zeng, 'Logistic Regression in Rare Events Data', Political Analysis, 9 (2001), 137-63. Results are equivalent using logit. A STATA 'do' file that replicates the analysis is available from the authors.

${ }^{102}$ Neal Beck, Jonathan Katz and Richard Tucker, 'Taking Time Seriously: Time-series-Cross-section Analysis with a Binary Dependent Variable', American Journal of Political Science, 42 (1998), $1260-88$.

103 David Strang, 'Global Patterns of Decolonization, 1500-1987', International Studies Quarterly, 35 (1991), 429-54, Appendix.

104 Hilde Ravlo, Nils Petter Gleditsch and Han Dorussen, 'Colonial War and the Democratic Peace', Journal of Conflict Resolution, 47 (2003), 520-48.

${ }^{105}$ Seymour M. Lipset, 'Some Social Requisites of Democracy: Economic Development and Political Development', American Political Science Review, 53 (1959), 69-105; Ross E. Burkhart and Michael S. Lewis-Beck, 'Comparative Democracy: The Economic Development Thesis', American Political Science 
National Material Capabilities dataset of total annual fuel consumption in coal-ton equivalents. $^{106}$ (2) Iron \& Steel/Pop. measures the quantity of iron (1816-99) or steel (1900-2000) produced by a country in a given year.

- Fighting Technology: No convention exists as to the measurement of fighting technology. Dupuy advocated an index where each weapon is given a lethality score. ${ }^{107}$ The index requires detailed information that makes it unworkable here. Furthermore, such an index does not really address a focus of our concern, the capital-intensiveness of a country's military organization. We adopt a simpler and more direct measure of fighting technology, dividing defence spending from the Correlates of War National Material Capabilities dataset (CINC) by the number of military personnel per country year. ${ }^{108}$ The result is a statistic analogous to GDP per capita identifying which armies have advanced weaponry etc., and which do not. ${ }^{109}$

- Democracy: Polity data provide indexes based on formal constraints on the executive (AUTOC) and institutional support for democracy (DEMOC). ${ }^{110} \mathrm{We}$ prepare monadic values by combining DEMOC and AUTOC scales as follows, [( DEMOC $\left.\left._{i}-\mathrm{AUTOC}_{i}\right)+10\right] / 2$, (where $i \in[\mathrm{A}, \mathrm{B}]$ ). We add 10 to make all values non-negative and divide by 2 to yield a $0-10$ index. We examine both the monadic values and higher and lower democracy scores for states in a dyad. ${ }^{111}$

- Fighting Effectiveness: Capabilities determine the ability of states to project power and conduct warfare abroad. We assess national military power or fighting effectiveness using the Correlates of War (COW) Composite Indicators of National Capabilities

(F'note continued)

Review, 88 (1994), 903-10; Håvard Hegre et al., 'Toward a Democratic Civil Peace? Democracy, Political Change, and Civil War, 1816-1992', American Political Science Review, 95 (2001), 33-48. The close fit between GDP and energy usage weakened after the 1970s oil shocks. Since our measures therefore underreport development, estimates will tend to fall short of actual support for the hypotheses.

106 J. David Singer, Stuart Bremer and John Stuckey, 'Capability Distribution, Uncertainty, and Major Power War', in Bruce M. Russett, ed., Peace, War, and Numbers (Beverly Hills, Calif.: Sage, 1972), pp.19-48; J. David Singer, 'Reconstructing the Correlates of War Dataset on Material Capabilities of States, 1816-1985', International Interactions, 14 (1987), 115-32; Correlates of War Project, National Material Capabilities Data Documentation, V. 3.0. State College, Pa.: The Pennsylvania State University, http://cow2.la.psu.edu/2005.

107 Dupuy, Numbers, Predictions and War; Trevor N. Dupuy, Understanding War: History and a Theory of Combat (New York: Paragon House, 1987).

${ }_{108}$ COW provides military expenditure agues in nominal (current year) British pounds (1816-1913) and US dollars (1914-2000). We used GDP deflators available at EH.net (URL: http://eh.net/hmit/) to obtain constant (2000) dollars. See Louis D. Johnston and Samuel H. Williamson, Economic History Services (Chicago, 2005); Lawrence H. Officer, Exchange Rate Between the United States Dollar and the British Pound, 1791-2004 (Chicago, 2004); Lawrence H. Officer, The Annual Real and Nominal GDP for the United Kingdom, 1086-2004 (Chicago, 2005). These documents and additional information are available at: http://www.measuringworth.com/index.php.

109 A lowess regression and scatter plot of the military technology variable on GDP per capita reveals the declining marginal relationship that is assumed by the model (plot available from the authors).

${ }^{110}$ Keith Jaggers and Ted R. Gurr., 'Transitions to Democracy: Tracking Democracy's "Third Wave" with the Polity III Data', Journal of Peace Research, 32 (1995), 469-82; Ted Robert Gurr, Keith Jaggers and Will H. Moore, 'Polity II: Political Structures and Regime Change' (unpublished Codebook, University of Maryland, 1989).

111 John R. Oneal, Bruce Russett and Michael L. Berbaum, 'Causes of Peace: Democracy, Interdependence, and International Organizations', International Studies Quarterly, 47 (2003), 371-93; John R. Oneal and Bruce Russett, 'The Kantian Peace: The Pacific Benefits of Democracy, Interdependence, and International Organizations', World Politics, 52 (1999), 1-37. 
(CINC) score. CINC scores are computed as the weighted average of a state's share of total system population, urban population, energy consumption, iron and steel production, military manpower and military expenditures. CINC is widely acknowledged as an approximation of national power.

- Major Power Status: Major powers tend to be more active internationally, resulting in more frequent conflict behaviour. Since they may also tend to be more capable and prosperous, there is a danger that the relationship between development and conflict might be confounded by major power politics. We include a dummy, Maj. Power, coded (1) for the major powers.

- Temporal Dependence: Finally, we control for temporal dependence by constructing four splines for each dependent variable, interpolated from a dummy matrix coding the lag between directed dyad years of conflict initiation or onset. ${ }^{112}$

\section{RESULTS}

Results of our analysis of development, democracy, technology, hegemony and colonies are summarized in two tables containing eight regressions. Each of the six regressions listed in Table 1 estimates the probability that a given country possesses at least one colony. Succeeding models introduce additional variables to test hypotheses, compare model specifications or assess robustness.

As Model 1 in Table 1 reveals, no simple monotonic relationship exists between economic development (Energy Cons./Pop.) and a nation's status as a colonial power. In contrast, both Hypothesis 2 and Hypothesis 3 appear to be borne out in these data. More capable countries (Fighting Effectiveness) are more likely to possess colonies, ceteris paribus, while nations with capital-intensive armed forces (Fighting Technology) are less inclined towards territorial imperialism. Contrary to Hypothesis 4, democratic countries appear much more likely to hold colonies. As we will see, this strongly counter-intuitive finding depends largely on the incomplete statistical model specification of Model 1. Major power status appears largely irrelevant for the possession of colonies.

The linear specification used for economic development in Model 1 may be inappropriate. Model 2 adds a quadratic term for economic development. ${ }^{113}$ Introducing the second quadratic term for development leads both coefficients to become highly statistically significant. Energy Cons./Pop. and its square produce the concave function predicted by Hypothesis 1. Fighting Effectiveness (Hypothesis 2) is positive and significant, though at a lower significance threshold than previously. The modest significance of the capabilities variable suggests that power is not as important a determinant of colonial status as other variables in the analysis, but this may be a by-product of the research design and available data. Our theory and available intuition suggest that Fighting Effectiveness was most salient during the onset of the colonial era, for the expansion of empire rather than for its demise. Of course, the dataset contains only a limited portion of the period of imperial expansion.

In contrast to the power variable, Fighting Technology becomes statistically significant at a much higher threshold in Model 2. Since the available data cover the entire period of

112 Beck, Katz and Tucker, 'Taking Time Seriously'.

113 We also examined a regression in which we added a quadratic term for fighting technology. Both the linear ( $(-)$ and exponential (+) fighting technology variables are statistically significant, but the overall effect of the two variables is negative for most values, with coefficients and means as follows: $(-58.098 \times 0.0190)+(149.924 \times 0.0025)=-0.7346$. 
TABLE 1 The Political Economy of Decolonization

\begin{tabular}{|c|c|c|c|c|c|c|}
\hline \multirow{2}{*}{ D.V.: Colonies } & \multicolumn{3}{|c|}{ Strang (1990) } & \multicolumn{3}{|c|}{ Ravlo et al. (2003) } \\
\hline & 1 & 2 & 3 & 4 & 5 & 6 \\
\hline Indep. Variables & $\begin{array}{l}\text { Coeff. } \\
\text { (S.E.) }\end{array}$ & $\begin{array}{l}\text { Coeff. } \\
\text { (S.E.) }\end{array}$ & $\begin{array}{l}\text { Coeff. } \\
\text { (S.E.) }\end{array}$ & $\begin{array}{l}\text { Coeff. } \\
\text { (S.E.) }\end{array}$ & $\begin{array}{l}\text { Coeff. } \\
\text { (S.E.) }\end{array}$ & $\begin{array}{l}\text { Coeff. } \\
\text { (S.E.) }\end{array}$ \\
\hline Energy Cons./Pop. & $\begin{array}{c}-0.0184 \\
(0.0172)\end{array}$ & $\begin{array}{l}1.255^{* * * *} \\
(0.329)\end{array}$ & $\begin{array}{l}1.182 * * * \\
(0.310)\end{array}$ & $\begin{array}{l}1.762 * * * \\
(0.394)\end{array}$ & $\begin{array}{l}1.293^{* * *} \\
(0.313)\end{array}$ & $\begin{array}{l}1.909 * * * \\
(0.399)\end{array}$ \\
\hline Energy Cons./Pop. ${ }^{2}$ & & $\begin{array}{l}-0.0922 * * * \\
(0.0267)\end{array}$ & $\begin{array}{c}-0.132 * * * \\
(0.0260)\end{array}$ & $\begin{array}{c}-0.166 * * * \\
(0.0435)\end{array}$ & $\begin{array}{c}-0.143^{* * * *} \\
(0.0368)\end{array}$ & $\begin{array}{c}-0.183^{* * *} \\
(0.0455)\end{array}$ \\
\hline Fighting Effectiveness & $\begin{array}{l}31.46^{* *} \\
(11.70)\end{array}$ & $\begin{array}{l}29.82^{*} \\
(13.58)\end{array}$ & $\begin{array}{l}27.00^{*} \\
(12.85)\end{array}$ & $\begin{array}{l}43.93 \\
(23.22)\end{array}$ & $\begin{array}{l}48.37^{*} \\
(24.29)\end{array}$ & $\begin{array}{l}41.17 \\
(24.40)\end{array}$ \\
\hline Fighting Technology & $\begin{array}{r}-14.76^{*} \\
(6.882)\end{array}$ & $\begin{array}{l}-42.92 * * * \\
(10.65)\end{array}$ & $\begin{array}{l}-66.55^{* * * *} \\
(14.83)\end{array}$ & $\begin{array}{l}-65.27 * * * \\
(17.79)\end{array}$ & $\begin{array}{l}-66.58^{* * *} \\
(12.80)\end{array}$ & $\begin{array}{l}-69.01 * * * \\
(18.68)\end{array}$ \\
\hline Energy $\times$ Fight Tech & & & $\begin{array}{l}8.580 * * * \\
(1.783)\end{array}$ & $\begin{array}{l}6.327^{* * *} \\
(1.450)\end{array}$ & $\begin{array}{l}6.646^{* * * *} \\
(1.044)\end{array}$ & $\begin{array}{l}6.639 * * * \\
(1.536)\end{array}$ \\
\hline Regime Type & $\begin{array}{l}0.190 * * * \\
(0.0486)\end{array}$ & $\begin{array}{c}0.0586 \\
(0.0518)\end{array}$ & $\begin{array}{c}0.0629 \\
(0.0542)\end{array}$ & $\begin{array}{c}-0.0276 \\
(0.0604)\end{array}$ & $\begin{array}{c}0.0487 \\
(0.0563)\end{array}$ & $\begin{array}{c}-0.0103 \\
(0.0649)\end{array}$ \\
\hline \# Colonies System & & & & $\begin{array}{l}6.145^{* * * *} \\
(0.904)\end{array}$ & & \\
\hline \# Colonies Hegemon & & & & & $\begin{array}{l}0.0618 * * * \\
(0.0143)\end{array}$ & \\
\hline Sys. Energy/Pop. & & & & & & $\begin{array}{l}12.35^{* * *} * \\
(3.424)\end{array}$ \\
\hline Sys. Energy/Pop. ${ }^{2}$ & & & & & & $\begin{array}{l}-4.099 * * * \\
(1.166)\end{array}$ \\
\hline US Energy/Pop. & & & & & & $\begin{array}{c}-2.317^{* * * *} \\
(0.585)\end{array}$ \\
\hline US Energy/Pop. ${ }^{2}$ & & & & & & $\begin{array}{l}0.168 * * * \\
(0.0417)\end{array}$ \\
\hline Major Power & $\begin{array}{c}0.850 \\
(0.776)\end{array}$ & $\begin{array}{c}0.683 \\
(0.929)\end{array}$ & $\begin{array}{c}0.518 \\
(0.973)\end{array}$ & $\begin{array}{c}0.805 \\
(0.964)\end{array}$ & $\begin{array}{c}0.685 \\
(0.952)\end{array}$ & $\begin{array}{l}1.036 \\
(1.061)\end{array}$ \\
\hline
\end{tabular}


TABLE 1

(Continued)

\# States in System

\# Major Powers

Intercept

$\begin{array}{cc}0.747 & 1.038 \\ (0.546) & (0.546) \\ 9671 & 9671\end{array}$

1.038
$(0.546)$
9671

$1.328 *$

(0.579)

9671

$-0.0365^{* *}$

$(0.0113)$

0.345

(0.186)

0.781

(1.364)

N

9671

9671
$-1.883 * *$
(0.701)

0.656

$(0.560)$

10474

Sig. levels: $\dagger: 10 \% ; *: 5 \% ; * *: 1 \% ; * * *: 0.1 \%$. Coefficients and S.E.'s for spline variables suppressed.

Sources: David Strang, 'From Dependency to Sovereignty: An Event History Analysis of Decolonization 1870-1987', American Sociological Review, 55 (1990), 846-60; Hilde Ravlo, Nils Petter Gleditsch and Han Dorussen, 'Colonial War and the Democratic Peace', Journal of

Conflict Resolution, 47 (2003), 520-48. For Relogit estimator, see Gary King and Kangche Zeng, 'Explaining Rare Events in International Relations', International Organization, 55 (2001), 693-715; and 'Logistic Regression in Rare Events Data', Political Analysis, 9 (2001), 137-63. 


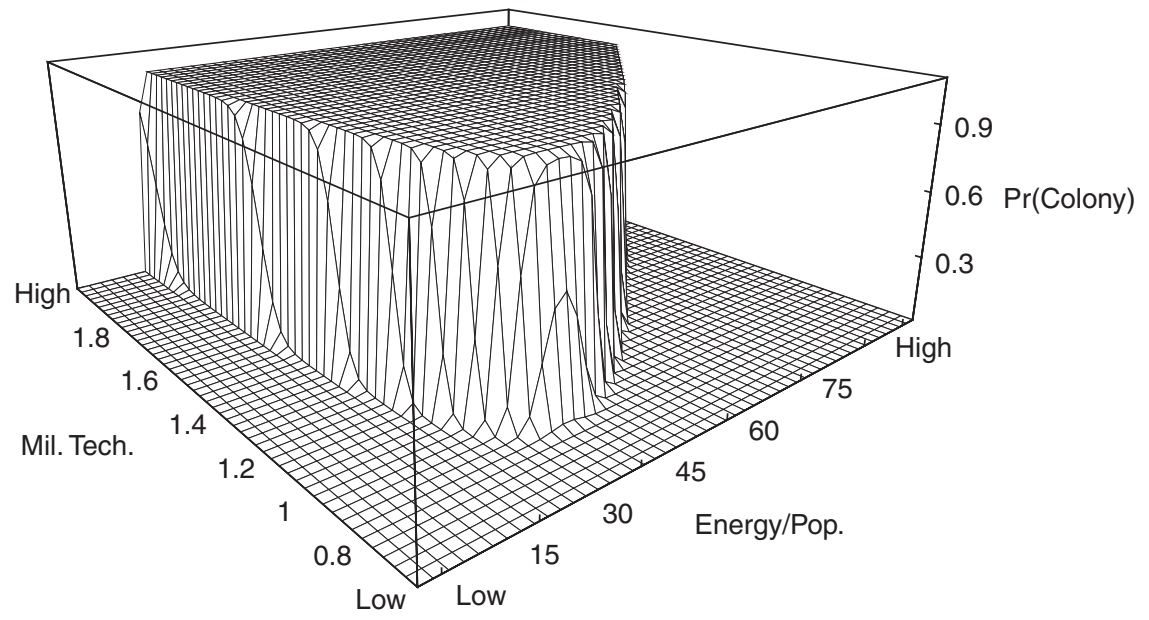

Fig. 3. Estimated effects of development and military technology on empire (Model 3)

decolonization, the mechanisms encouraging the end of empire are able to perform more effectively, especially with the proper model specification. With the addition of a second term for economic development, the Regime Type variable is no long positive and significantly significant, though the relationship remains positive. It appears that democracy does not influence decolonization one way or the other (Hypothesis 4). The major power status variable also continues to be statistically insignificant.

Civilian and military technology are of course related. ${ }^{114}$ Treating the two processes as independent, when they are not, risks biasing estimates of their respective independent effects. Model 3 adds an interaction term between Energy Cons./Pop. and Fighting Technology. Energy $\times$ Fight Tech . is statistically significant and positive indicating that, for small values of Fighting Technology, increases in civilian economic development tend to increase the probability of colonial holdings. While there is some synergy between civilian and military technology, all three development and technology variables remain highly statistically significant in the presence of the interaction term.

Figure 3 offers a three-dimensional plot of the predicted probability of an independent country possessing at least one colony based on Model 3. Development (Energy/Pop.) increases from left to right, while fighting technology (Mil. Tech.) increases from front to back in the image. The probability of colonial possessions is plotted on the vertical axis. The resulting plot looks roughly like a 'grand piano', 'mesa' or the bow of a ship (facing slightly right of the reader). Recall that in the formal model, fighting technology is a declining function of development. Imagine beginning in the left foreground of the figure (low Energy/Pop. and Mil. Tech.) and moving in a diagonal line towards the most advanced countries (high Energy/Pop. and Mil. Tech.). The declining marginal impact of development on fighting technology leads the trajectory of a nation to veer right as we travel first up to the piano/mesa/boat, and then down again to the floor/valley/water on the right side of the figure.

114 Energy Cons./Pop. and Fighting Technology are moderately correlated $(r \approx 0.3)$. While linear and squared terms are highly correlated, multicollinearity is not indicated, as the linear terms are statistically insignificant by themselves, the non-linear variables are significant, other variables are unaffected, and theory dictates this specification. 
TABLE 2 Political Economy and the Number of Colonies

\begin{tabular}{|c|c|c|c|c|}
\hline \multirow{3}{*}{$\begin{array}{l}\text { D.V.: \# of Colonies } \\
\text { Indep. Variables }\end{array}$} & \multicolumn{2}{|c|}{ Strang (1990) } & \multicolumn{2}{|c|}{ Ravlo et al. (2003) } \\
\hline & \multicolumn{2}{|c|}{7} & \multicolumn{2}{|c|}{8} \\
\hline & Coeff. & (S.E.) & Coeff. & (S.E.) \\
\hline $\begin{array}{l}\text { Energy Cons./Pop. } \\
\text { Energy Cons./Pop. }\end{array}$ & $\begin{array}{c}0.871^{* *} \\
-0.094 * * *\end{array}$ & $\begin{array}{l}(0.281) \\
(0.029)\end{array}$ & & \\
\hline $\begin{array}{l}\text { Iron \& Steel/Pop. } \\
\text { Iron \& Steel/Pop. }\end{array}$ & & & $\begin{aligned} & 17.297 * * * \\
- & 29.698 * *\end{aligned}$ & $\begin{array}{r}(4.676) \\
(10.034)\end{array}$ \\
\hline Fighting Effectiveness & 7.712 & $(7.711)$ & $26.749 \dagger$ & $(15.890)$ \\
\hline Fighting Technology & $-26.300 * *$ & $(9.395)$ & $-24.975^{*}$ & $(11.272)$ \\
\hline Dev. $\times$ Fight Tech. & $3.023 \dagger$ & $(1.602)$ & $45.906 \dagger$ & $(25.591)$ \\
\hline Regime Type & 0.066 & $(0.051)$ & $-0.114 \dagger$ & $(0.063)$ \\
\hline \# Colonies Hegemon & $0.027 * * *$ & $(0.007)$ & $0.035^{* * *}$ & $(0.005)$ \\
\hline Major Power & $1.614^{*}$ & $(0.780)$ & 0.269 & $(0.986)$ \\
\hline Intercept & $-1.962 *$ & $(0.834)$ & $-3.762 * * *$ & $(0.451)$ \\
\hline$/ \ln (\alpha)$ & $2.311 * *$ & $(0.331)$ & $1.273 * *$ & $(0.311)$ \\
\hline $\begin{array}{l}\mathrm{N} \\
\text { Log-likelihood } \\
\chi_{(8)}^{2}\end{array}$ & $\begin{array}{r}9 \\
-81 \\
7\end{array}$ & & $\begin{array}{r}1 \\
-89 \\
20\end{array}$ & \\
\hline
\end{tabular}

Sig. levels: $\uparrow: 10 \% ; *: 5 \%$; *: $1 \%$; ***: $0.1 \%$. Spline variables suppressed.

Notes: The values displayed are negative binomial regression coefficients.

Notice also that the transition to and from colonialism is abrupt. Colonial holdings were acquired as nations expanded their ability to subdue distant territories. They were abandoned suddenly, collectively, as if the logic of empire had suddenly fallen off a cliff.

While Hypotheses 1 through 3 are supported, but not Hypothesis 4, we have yet to assess the systemic and hegemonic hypotheses. Models 4 and 5 in Table 1 introduce variables for the number of colonies in the system (Hypothesis 5) and the number of colonies held by the hegemon (Hypothesis 6). Neither hypothesis can be rejected. ${ }^{115}$ Systemic and hegemonic colonial portfolios clearly influence individual national decisions to maintain or abandon empire. By 'crowding out' access to markets and raw materials, the presence of colonies in the system appears to have led to additional acts of imperialism by other nations. Conversely, as soon as the hegemon or other nations abandoned empire, countries found perpetuation of a colonial system to be less necessary.

Model 6 completes Table 1 by introducing variables to evaluate systemic development, the effects of American hegemony, and to control for factors relevant to the systemic variables. ${ }^{116}$ Consistent with Hypothesis 7, Sys. Energy/Pop. and its square reveal a concave relationship between systemic development levels and the appeal of colonies. Development initially leads to systemic predation as states compete to capture resources and markets. These incentives reverse themselves, however, as the gains from production ( $A$ in the formal model) increase with development and the gains from trade $(B)$ grow

\footnotetext{
115 A variable coded for the proportion of territories that are colonies (colonies/(colonies + countries)) yields equivalent results.

${ }^{116}$ We drop the \# Colonies variables that are highly collinear with the systemic/hegemonic development variables.
} 
TA B LE 3 Descriptive Statistics for All Variables Used in Table 1 and Table 2

\begin{tabular}{lccccc}
\hline \hline Variable name & Obs. & Mean & Std. Dev. & Min. & Max. \\
\hline Dependent Variables & & & & & \\
Colony Dummy (Strang) & 10300 & 0.1574757 & 0.3642664 & 0 & 1 \\
Colony Dummy (Ravlo et al.) & 11115 & 0.1964912 & 0.3973621 & 0 & 1 \\
Colony Count (Strang) & 10300 & 1.710291 & 7.495472 & 0 & 73 \\
Colony Count (Ravlo et al.) & 11115 & 1.301664 & 4.955584 & 0 & 50 \\
Key Indep. Variables & & & & & \\
Energy Cons./Pop. & 12590 & 1.683821 & 5.273448 & 0 & 87.94954 \\
Energy Cons./Pop. & 12590 & 30.6423 & 291.3086 & 0 & 7735.122 \\
Iron \& Steel/Pop. & 13008 & 0.1155529 & 0.7869664 & 0 & 18.16338 \\
Iron \& Steel/Pop. & 13008 & 0.6326209 & 9.46593 & 0 & 329.9084 \\
Energy X Mil. Tech. & 12590 & 0.1119399 & 1.067389 & 0 & 60.71391 \\
Fighting Technology & 13212 & 0.0190369 & 0.0459871 & 0 & 2.797716 \\
Fighting Technology & 13212 & 0.0024771 & 0.087587 & 0 & 7.827213 \\
Fighting Effectiveness (CINC) & 13020 & 0.0146515 & 0.0392248 & 0 & 0.383864 \\
Regime Type & 12925 & 4.142592 & 3.533467 & 0 & 10 \\
\# Colonies System (Strang) & 10482 & 94.21847 & 35.38304 & 35 & 148 \\
\# Colonies System (Ravlo et al.) & 13020 & 57.48694 & 40.79045 & 0 & 120 \\
\# Colonies (proportion, Ravlo) & 13020 & 0.3862178 & 0.2874053 & 0 & 0.7964602 \\
\# Colonies (proportion, Strang) & 10482 & 0.5435864 & 0.2140161 & 0.1785714 & 0.8130081 \\
\# Colonies Heg. (Strang) & 13212 & 17.18377 & 23.27788 & 0 & 73 \\
\# Colonies Heg. (Ravlo et al.) & 13020 & 9.106836 & 15.38836 & 0 & 48 \\
US Energy/Pop. & 13212 & 7.16194 & 3.916243 & 0 & 11.67185 \\
US Energy/Pop. & 13212 & 66.62918 & 46.14584 & 0 & 136.2322 \\
Sys. Energy/Pop. & 12829 & 1.388583 & 0.7335191 & 0.1209896 & 2.290689 \\
Sys. Energy/Pop. & 12829 & 2.466171 & 1.890983 & 0.0146385 & 5.247256 \\
Other Indep. Variables & & & & & \\
Major Power & 13212 & 0.0830306 & 0.2759389 & 0 & 1 \\
\# States in System & 13212 & 105.9584 & 58.13557 & 23 & 192 \\
\# Major Powers & 13212 & 5.824932 & 1.047652 & 4 & 8 \\
'Colony year' (Strang) & 10300 & 34.96078 & 38.14619 & 0 & 170 \\
'Colony years'(Ravlo et al.) & 11115 & 31.89051 & 37.06093 & 0 & \\
\hline \hline & & & & & \\
\hline
\end{tabular}

Sources: David Strang, 'From Dependency to Sovereignty: An Event History Analysis of Decolonization 1870-1987', American Sociological Review, 55 (1990), 846-60; Hilde Ravlo, Nils Petter Gleditsch and Han Dorussen, 'Colonial War and the Democratic Peace', Journal of Conflict Resolution, 47 (2003), 520-48.

with the size of the world economy. Similarly, the appeal of colonization appears to ebb with increases in American productivity, though at a declining marginal rate. As the chief proponent, and beneficiary, of free trade in the twentieth century, the United States possessed few incentives to prop up the European colonial system when the United States became a hegemon. We add \# States in System and \# Major Powers to evaluate the effects of changing system structure and size. Having more major powers in the system does not significantly increase territorial empire once monadic and systemic development, technology and other factors are considered. The number of states in the system is negatively associated with colonialism, though these two variables are of course rough complements.

Table 2 lists two negative binomial regressions, each estimating the number of colonies a country holds. Theoretical expectations for the count of colonies are less precise 
than for the dichotomous variable. Still, results are substantially consistent with those in Table 1. Model 7 reports the curvilinear relationship between development and the count of colonies. Fighting Technology is again negative and significant, while the interaction term between development and military technology is again positive. The power variable (Fighting Effectiveness) is positive, though significant only in Model 8. The number of colonies held by the hegemon significantly increases colonialism by other states, while state capabilities or major power status have modest effects. Model 8 substitutes iron and steel production per capita for energy consumption. ${ }^{117}$ Regime Type becomes marginally significant in the expected direction for the first time. Six of our seven hypotheses are thus consistently supported. The fact that democracy is usually insignificant suggests that while institutionalist arguments are logically tenable, popular rule does not appear to impact imperialism in practice.

\section{CONCLUSION: ONCE AND FUTURE EMPIRE?}

The lust for territory subsided among powerful nations as it became cheaper to make than to take, and as the global mercantilist system gave way to freer trade. Empire is unappealing when appropriative technology is low, domestic labour is scarce or when global markets are obstructed.

In contrast, the desire to control land, rooted labour and minerals remains strong in the developing world. Poor countries still covet territory, though they often lack the capacity to project power beyond their borders. In places where labour is cheap and abundant and capital is expensive, conquest and other activities designed to allow the state to acquire a larger pool of rents will remain appealing. A final factor is American enforcement of a norm of territorial integrity, though this could decay if the United States weakens or developing states become more capable of conquest. ${ }^{118}$

Paradoxically, successful development could increase the number of 'middle tier' economies, which could then overwhelm internal or external inhibitions against territorial aggression. Rapid development could see nations cross the military effectiveness threshold $(\hat{\rho})$ faster than the rise in the cost of labour. At the same time, technological innovation might again increase the ability of the most advanced nations to take rather than make. Automation and smart weaponry could dramatically lower the cost of empire. Alternatively, political instability or dramatic price increases in critical resources could spark efforts to control mineral-rich regions. Global political competition could also ignite efforts to capture and control scarce minerals. We must hope that rising powers see themselves as beneficiaries of the global economy and endorse open markets in due course.

Finally, what should be made of the revived empire debate? At least some of the controversy follows from different conceptions of what empire entails. Proponents of American Exceptionalism seem in fact to be advocating American leadership. To the degree that our results suggest an important role for the hegemon in promoting open markets, we can support this limited form of leadership. However, much of the advocacy

117 All models presented in this analysis have been replicated using iron and steel production in place of the energy consumption variables. In most cases, the iron and steel production variables provide an even better fit than energy consumption. However, the interaction term between iron and steel production and military technology is generally not statistically significant. All results are available from the authors.

118 Zacher, 'The Territorial Integrity Norm'; Tanisha Fazal, 'State Death in the International System', International Organization, 58 (2004), 311-44. 
is overblown and confused, precisely because sponsorship of global markets limits the incentives for powerful states to pursue other aspects of empire. Critics, too, seem to exaggerate the continuity between recent American policies and earlier incarnations of territorial empire. There is something different about how the current hegemon treats territory, but in contrast to George W. Bush, we see this change as applicable to every nation, not just the United States. 